\title{
Inventors and Innovators: Naval Lighterage and Anglo-American Success in the Amphibious Invasions of German-Occupied Europe
}

\section{Frank A. Blazich, Jr.}

The amphibious invasions of Sicily, Salerno, and Normandy all made ample use of US Navy landing pontoons. The simple steel box pontoons were the brainchild of civil engineer Captain John $N$. Laycock, who developed and perfected his inventive design on the eve of American entry into World War II. Once in the conflict, a Royal Navy reserve officer assigned to Combined Operations Headquarters, Captain Thomas A. Hussey, conceptualized innovative uses for the American pontoons for offensive amphibious operations. Working together, these men developed pontoon causeways and massive lighterage barges which ensured logistical success in the invasions of German-occupied Europe.

Les invasions amphibies de la Sicile, de Salerne et de la Normandie ont toutes fait appel aux pontons de débarquement de la Marine américaine. Les simples pontons flottants en acier ont été créés par le capitaine John N. Laycock, ingénieur civil, qui a développé et perfectionné sa conception géniale à la veille de l'entrée des États-Unis dans la Seconde Guerre mondiale. Une fois le conflit déclenché, le capitaine Thomas A. Hussey, officier de réserve de la Marine royale affecté au quartier général des opérations combinées, a mis au point des utilisations novatrices des pontons américains pour les opérations amphibies offensives. La collaboration de ces deux hommes a permis de développer des chaussées de pontons et d'énormes barges de chalandage qui ont assuré le succès logistique des invasions de l'Europe occupée par les Allemands.

The Northern Mariner / Le marin du nord 31, no. 2 (Summer 2021), 125-172 
In mid-June 1944, followers of war correspondent Ernie Pyle read of his journey to the Normandy beachhead aboard the landing ship, tank (LST) LST-353 as part of the Allied invasion of France. Steaming in a convoy, Pyle mentioned how each ship towed "a big steel pontoon section, to be used as barges and docks in the shallow waters along the beach. And behind each pontoon we also towed a smaller pontoon with two huge outboard motors on it - a thing called a "rhino." Perhaps bemused, he nonetheless spoke favorably about the slow-moving rhino which brought him to shore at Omaha Beach on 7 June while a passenger in a jeep. Anticipating getting drenched coming ashore, the veteran correspondent pleasantly found that the "water came only to the floor of our jeep. We didn't even get our feet wet...."2 Pyle shared with the American public what thousands of American GIs came to appreciate in the days and weeks after the invasion: the relative ease of arriving in France by walking or driving across one of the US Navy's most valuable logistical tools of World War II.

Pyle and countless others did not know the names of the men who developed the means to "bridge the gap" from ship to shore. Nor did they know of the key roles of an American inventor and a British innovator in maximizing the usage of an unsung, critical element in the naval logistical effort to supply and out-equip the adversary: US Navy landing pontoons. Conceived in the 1930s and refined on the eve of American entry into the war, the T-series of landing pontoons would serve in amphibious operations in both the Atlantic and Pacific Theaters. Elegantly simple in form and function, a small Anglo-American partnership would develop a series of innovative pontoon ferries and causeways for the invasion of Germanoccupied Europe to ensure a steady flow of vehicles and supplies would land on five invasion beaches along the Normandy coast and secure a lodgment in France for the liberation of Western Europe.

\section{The Inventor and his Creation}

The brainchild behind the Navy landing pontoon was Methuen, Massachusetts native John Noble Laycock. He graduated from the US Naval Academy in 1914, having been described by his fellow midshipmen as "congenial beyond congeniality" and "naturally brilliant." In 1915, Laycock successfully submitted a request to transfer to the Civil Engineer Corps (CEC). Enrolling in Rensselaer Polytechnic Institute in Troy, New York for postgraduate instruction, he graduated in 1917 with a Bachelor of Science in Civil Engineering. On 6 June he received a promotion to lieutenant (junior grade) and formally transferred from the line to the CEC and served ashore at a variety of locations in the United States and Canal Zone. From 1927-31, Laycock served as a treaty engineer in the Republic of Haiti

\footnotetext{
Ernie Pyle, “Too Sleepy to Worry about Dangers of Channel Trip,” Sioux City Journal, 15 June $1944,1$.

2 Ernie Pyle, "Abroad, Somewhere in France," Palladium-Item (Richmond, IN), 21 June 1944, 6. 3 United States Naval Academy, The Lucky Bag, 1914 (Philadelphia, PA: William H. Hoskins Co., 1914), 142.
} 
in municipal engineering and public works administration.

Returning to the United States in October 1931, Laycock's career kept him largely in New England. After service at the Boston Navy Yard, in 1937 he received orders to become Public Works Officer and Officer in Charge of a Works Progress Administration program at the Portsmouth Navy Yard in Maine. ${ }^{4}$ At Portsmouth, long hours of work began to take a toll on his health. By 1938, he was experiencing severe headaches, eyestrain, partial deafness, and facial pains. These health issues delayed his acceptance of an offer from Rear Admiral Ben Moreell, Chief of the Bureau of Yards and Docks (BuDocks), to transfer to the bureau headquarters in Washington, DC. Arriving in Washington in mid-March 1939, Laycock became the bureau's War Plans Officer. ${ }^{5}$ In his new position at BuDocks, duty considered "less strenuous and with less responsibility," Laycock found himself tasked with reviewing and preparing the bureau's sections of the Navy's various war plans. ${ }^{6}$

Foremost among these was War Plan Orange conceived in the event of war between the United States and the Japanese Empire. With an objective of military victory and a strategy of unlimited economic war, the plan evolved from a short engagement to a protracted conflict. For over two decades, planners had opted for the "Through Ticket to Manila," whereby the Pacific Fleet would rush to the Philippines as soon as possible to establish a base near Japan. A countering plan, the "Cautionary Strategy," involved establishing a series of advanced fixed and mobile bases on islands to ensure a methodical but strong crossing of the Pacific. In consideration of the geographic scale of the Pacific Ocean, planners and strategists recognized the need to seize and develop advanced bases to resupply and repair the Pacific Fleet and secure logistical and communication lines. ${ }^{7}$

Following revisions, discussions, and war games of the "Through Ticket" and the "Cautionary Strategy" plans, a focused War Plan Orange began to coalesce in the 1930s under the administration of President Franklin D. Roosevelt. The Navy ended support of the "Through Ticket" and opted for the "Cautionary Strategy." The Naval War Plans Division in turn reached out to BuDocks to contribute its resources to the development of the advanced fixed and mobile bases. ${ }^{8}$ The primary BuDocks contribution to the mobile base component of War Plan Orange involved the development of floating dry docks, a critical component to the fleet's mobility

\footnotetext{
4 "Army and Navy Orders," Washington Times (DC), 4 October 1915, 12; "Civil Engineer Vacancies," Washington Post, 11 June 1916, 13; Bureau of Yards and Docks (BuDocks), Biographical File, "Captain John Noble Laycock, (Civil Engineer Corps), US Navy, Retired," 29 January 1947; John N. Laycock to Helen R. Fairbanks, 24 October 1960, US Navy Seabee Museum Archives, Port Hueneme, CA (SMA).

Charles Matthews, "John Laycock, CEC, USN: Patron of the Pontoon," Navy Civil Engineer (August 1968): 9; Charles Matthews, untitled draft for article about John Laycock, 26 April 1967, 2-6, SMA.

Matthews, untitled draft, 2, SMA.

Edward S. Miller, War Plan Orange: The US Strategy to Defeat Japan, 1897-1945 (Annapolis, MD: Naval Institute Press, 1991), 3-5, 27-37.

$8 \quad$ Miller, War Plan Orange, 180-82, 210.
} 
which later proved invaluable in the Pacific War. ${ }^{9}$ For the fixed advance bases located at various Pacific atolls, BuDocks faced a number of logistical challenges in constructing naval bases equipped with airfields, hospitals, fuel and supply dumps, ammunition magazines, machine shops, and more. Everything to construct the fixed advance bases would need to be packaged and shipped across the Pacific, requiring the acquisition or development of an array of specialized equipment. ${ }^{10}$

BuDocks established a War Plans Section when the bureau began contributing to the development of War Plan Orange in the early 1930s. The bureau confronted an array of unresolved questions ranging from personnel to technologies to solve the primary issue: building a naval base in a remote, undeveloped location. In 1932, Captain Carl A. Carlson, CEC, began contemplating the use of standardized pontoon units and the assorted challenges of transporting and assembling the pontoons at the advanced bases. ${ }^{11}$ His successor, Captain Walter H. Allen, CEC, investigated some of the technical aspects of advance base equipment. Navy lighterage, the movement of cargo between vessels of differing sizes, was but one aspect to be worked out, as was the movement of cargo and supplies from ships to a primitive shore. Allen, together with Lieutenant Commander Raymond V. Miller, CEC, envisioned the lighterage equipment as "completely fabricated units" which would be carried as a deck load for swift offloading at the advance base location. These structures could then be joined together to form lighters, pile driver pontoons, or other structures as required to offload cargo ships. ${ }^{12}$ Recalled Miller, drawings and descriptions for fabricated sectional pontoon units "were in the Bureau's war plans safe when I was detached ... in late August of 1934."13

In the following years, through conversations with Lieutenant Commander Paul W. Hains, Construction Corps, a superintending constructor for the Navy's Bureau of Construction and Repair, Allen gathered additional ideas and information about commercially available lighterage technology. In 1936, Hains found himself assigned as the superintending constructor at the Union Iron Works in San Francisco, a subsidiary of the Bethlehem Ship Building Corporation. While in the construction yard overseeing projects for the Navy, he noticed the assembly of a sectional steel barge for use in supporting a gold dredge. While not necessarily a "eureka" moment, Hains nonetheless struck pay dirt. Assembly and operation in remote areas necessitated the dredges having a sectional design. A large pontoon barge floated in a pond which supplied the water for the dredge's sluicing

9 John T. Kuehn, Agents of Innovation: The General Board and the Design of the Fleet that Defeated the Japanese Navy (Annapolis, MD: Naval Institute Press, 2008), 125-43.

10 Miller, War Plan Orange, 210.

11 Vincent Transano, "History of the Seabees," Naval Facilities and Engineering Command, 1996; United States Navy, Building the Navy's Bases in World War II: History of the Bureau of Yards and Docks and the Civil Engineer Corps, 1940-1946, Vol. 1 (Washington, DC: Government Printing Office (GPO), 1947), 133-49; Matthews, "Patron," 9.

12 Raymond V. Miller to Walter H. Allen, 5 November 1934; Walter H. Allen to Raymond V. Miller, 31 October 1934, SMA.

13 Raymond V. Miller to John J. Manning, 31 October 1949, SMA. 
operations. ${ }^{14}$ Hains, recognizing the sectional value of the dredge barge for Navy purposes, wrote to Allen on 10 March to share information about the pontoons. Through continued correspondence with Allen, Hains provided a drawing of how he believed steel box sections could be connected to form a barge. His design used $10 \times 20 \times 6$-foot steel boxes with internal stiffening plates. Each incorporated a manhole on the upper surface to allow interior access. Heavy bolts would connect the adjoining sections through holes in the side close to the top and bottom plates. Conical bushings (male and female on adjoining sections) would center the bolt holes and protect against shear stresses. The actual assembly of the sections would involve a man climbing inside the units to individually pass the bolts through the connecting holes. Allen filed Hains' sketch in the bureau's War Plans Section files, but no further work proceeded on the matter. ${ }^{15}$

Upon his arrival in Washington in March 1939 as the new War Plans Officer, Laycock found himself tasked with writing the BuDocks appendix to the Navy's revised Basic Readiness Plan. After finishing this planning work by summer, he turned his attention to the installation and assembly of advanced bases which remained undeveloped. Laycock recognized through a study of existing base plans for the Pacific the Navy's requirement for portable or mobile equipment of universal utility, all designed or selected to expeditiously assemble the advanced bases. Several of the required pieces of equipment simply did not commercially exist, principally portable power and saltwater distillation plants, housing facilities, and specialized pontoon gear. ${ }^{16}$

Examining the pontoon-related material in BuDock's files, Laycock studied Hains' sketch for sectional pontoons. The CEC officer noted two primary faults with the Hains proposal, mainly the risk of danger to the men assembling the pontoon, and inadequate strength of the finished assembly. Laycock continued to contemplate the pontoons and the respective uses of such an assembly into early 1940. In July, a new assistant joined Laycock in the War Plans Section, Lieutenant Commander Everett S. Huntington, CEC. Together, they hashed out the pontoon as a universal-sized unit, multiples of which could be assembled to form barges, sea plane ramps or floating dry docks. Regarding the maximum weight a barge might be called upon to move, both men worked on a barge design able to haul a large caliber naval gun of up to 120 tons. $^{17}$

Around this same time, Laycock decided to build a model for experimentation. In the Main Navy Building along the National Mall in Washington, DC, Laycock asked every concessionaire to save empty cigar boxes for him. With the help of a

14 Noel W. Kirshenbaum, "The Giant Gold Diggers: California's Land-Going Fleet of Dredges" Mining History Journal 7 (2000): 11-23.

15 Document, "Notes on the Development of Pontoon Gear (Based on Interview with Capt. Laycock - 24 May 1944)," SMA; Navy Department, Bases, Vol. 1, 157.

16 Document, "Interview with Captain Laycock - 11, 12, 13 May 1944," SMA; Navy Department, Bases, Vol. 1, 8, 151 .

17 Document, "Interview with Laycock"; document, "Notes on Development," SMA. 


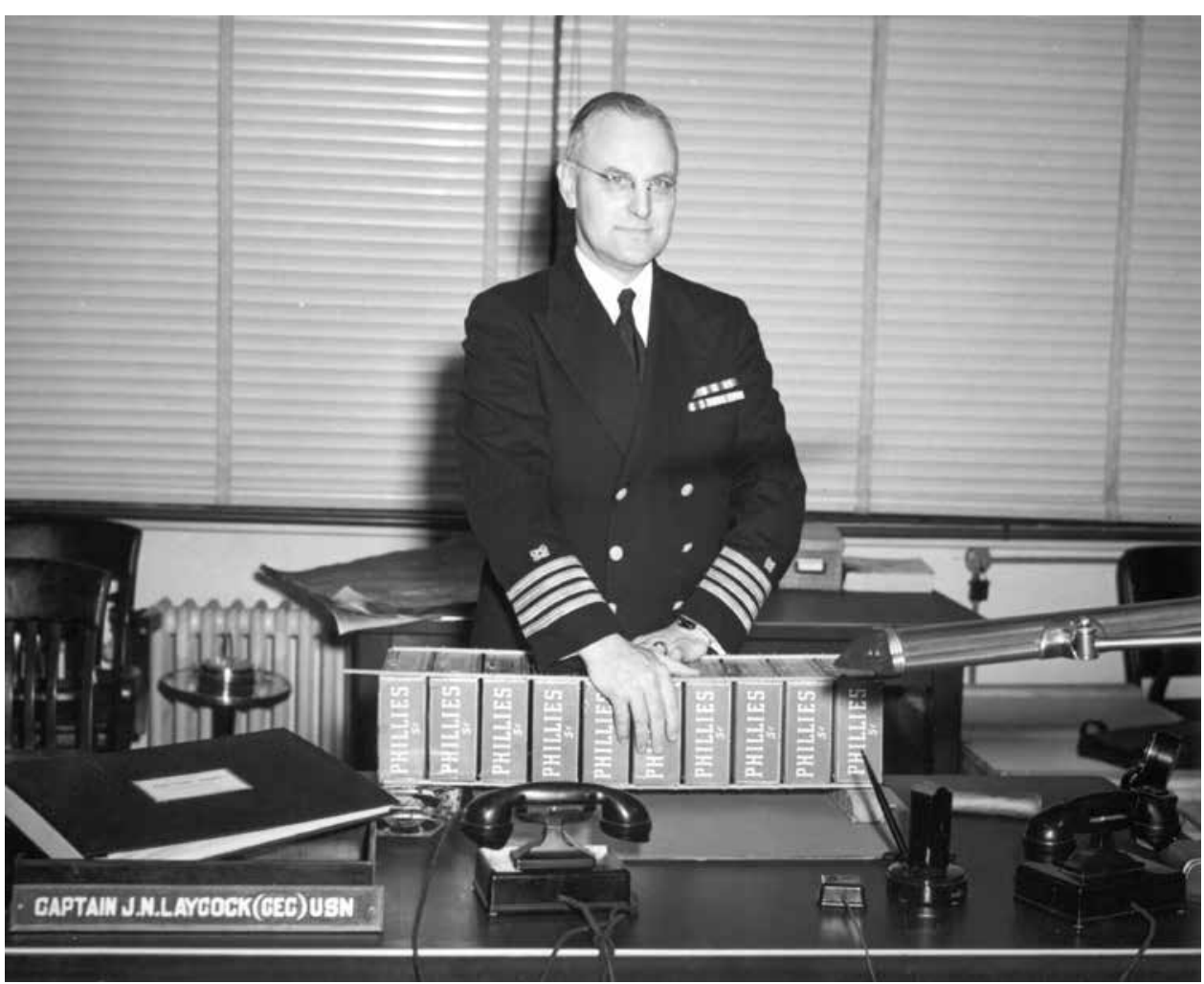

Captain John Noble Laycock, Civil Engineer Corps, USN, with his cigar box model. (US Navy Seabee Museum, Port Hueneme, CA)

civilian employee of the bureau, C.W. Ingram, Laycock evenly spaced the boxes and linked them together in a string using wood model kite sticks fastened to the corners of the boxes with small nuts and screws. With the use of these wood strips, the model demonstrated the feasibility of connecting individual pontoon boxes using continuous angles (via the wood strips) to create a well-diaphragmed sectional box girder. In simpler terms, the structural rigidity of a single pontoon could be imparted to a combination of pontoons, opening the possibility of making an almost unlimited number of combinations through standardized pontoons and connections. On 23 July, Laycock drafted a memorandum on the "Requirements for Landing Gear" where he outlined the need for continuous steel angles (substituting for his wooden kite sticks) to link the sectional pontoons spaced nine inches apart in the string. Critical problems, however, remained to be resolved for fastening and assembling the pontoons into strings. ${ }^{18}$

Either before or after his memorandum, Laycock discussed the fastening and assembling problems with Albert J. Dawson, chief engineer of the Dravo Contracting Company of Pittsburgh. The primary obstacles to overcome were developing a method to avoid the bending moments caused by the eccentricity of

18 Document, "Interview with Laycock"; document, "Notes on Development," SMA. 
the load transfer when the fastening bolts were offset some distance from the top and bottom plates of the pontoons. Second was to provide a means to make and launch small strings of pontoons for combination into larger multi-string structures. An associated third problem entailed developing a safe method of assembly for the personnel involved. Laycock hoped for Dawson and Dravo to help the bureau resolve these problems. While on a month's leave in August, Laycock drove to Pittsburgh and met with Dawson as well as company president, Vere B. Edwards, and other officials to see if they would take up the task of working out the details of the physical pontoons and the fastenings. From Pittsburgh, Laycock drove to New Hampshire, under the impression Dravo would send him a proposal for their engineering services within days.

After a week of silence from Dravo, Laycock lost patience and chose to figure out the problems himself. For the remainder of his family vacation, Laycock chewed through the problems, in his own words working "in pretty much of a trance." Laycock's mind returned to his cigar box model and the wood sticks. As proposed in his 23 July memo, the continuous steel angles would be able to carry the major tension and compression stresses for the assembled string. The devices thus only had to carry the increment of stress incident to the increase in movement from pontoon to pontoon. If there was no continuous angle, the stress from each pontoon's movement in a string would accumulate in the fasteners themselves and increase the likelihood of failure. Since the continuous angle functioned as the primary strong point in the assembly, the connecting fasteners could be relatively light.

To form the continuous angles between the steel angle and each individual pontoon box, Laycock needed room for his fasteners. He therefore opted to cut away the corners of the pontoons, cover the triangular opening with plate steel, and then weld on a connecting angle strap with holes to enable assembly of the individual boxes to the continuous angles. For his cigar box model, Laycock opted for screws, nuts, and washers to connect the boxes and wood angles. For the steel pontoons Laycock scaled up the screw into a $1 \frac{1 / 2}{2}$ steel assembly bolt that would be inserted by hand and tightened to a nut welded to the connecting angle strap on the pontoon corners. To compensate for unequal tightening of all the bolts in a pontoon assembly, Laycock used one set of bolts to directly connect the angles to the pontoons, and a second arrangement of specialized connections involving a wedge bolt, diagonal wedge, and wheel nut that could be installed by hand without tools, a vast improvement over the assembly method in Hains' mid-1930s suggestion. To connect strings of pontoons to form larger structures, Laycock opted to use simple tie rods on the underside of the resulting structure. ${ }^{19}$

With the fastenings worked out, Laycock could next determine the criteria for the physical dimensions of the pontoons. Although unclear in the historical record, Laycock most likely worked out the dimensions upon his return to BuDocks

19 Document, "Notes on the Development," SMA. 


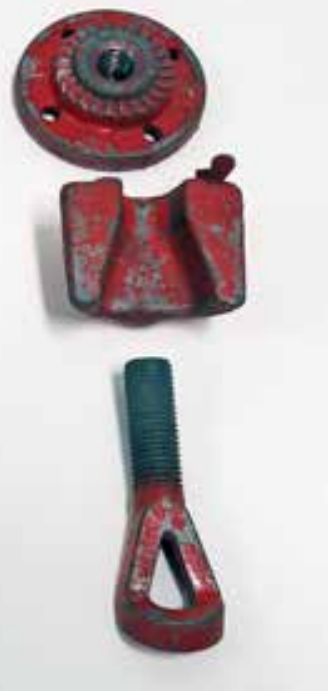

Pontoon "jewelry," consisting of the wedge bolt, diagonal wedge, and wheel nut.

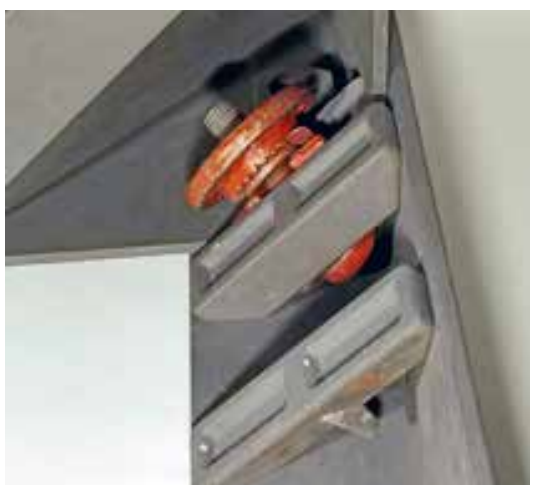

The jewelry installed on a 1:1 scale wood model of the steel angle and the corner strap of a pontoon.

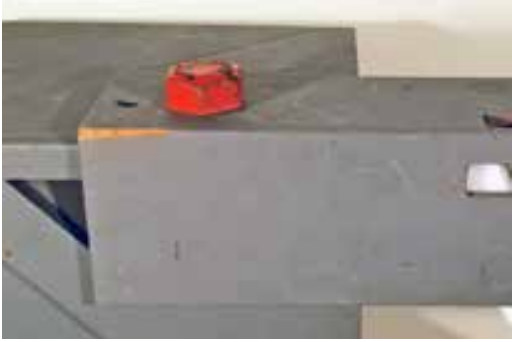

A $1 \frac{1}{2}$ " steel assembly bolt mounted on a 1:1 scale wood model of a steel angle to a pontoon. (National Museum of American History, Washington, DC) headquarters in Washington. Seven criteria would factor into the final dimensions. These included:

1. The width of the largest steel plate used could not exceed the width of plates usually rolled in large quantities in mills.

2. The width of a pontoon string would have to be great enough to allow stability when afloat.

3. The empty weight of an empty pontoon should be one ton.

4. The top surface of the pontoon should be capable of supporting a ten ton load from each of two dual tires (an equivalent load of ten tons on a twenty inch square).

5. When filled with gasoline, an individual pontoon should weigh approximately five tons, the normal capacity of cargo booms on merchant ships.

6. There should be a total width of about twenty feet when three pontoon strings were assembled and connected side to side.

7. The draft of a pontoon when unloaded should be about sixteen inches.

Through trial and error, by October Laycock determined the ideal pontoon dimensions to measure five by seven by five feet. ${ }^{20}$

The basic shape determined, Laycock and fellow BuDocks employees next tackled the design of the fasteners required to connect the pontoons to the continuous steel angles. A civilian draftsman whose name is lost to the record used his home woodshop to construct models to test out Laycock's drawings and designs for the fasteners, all unique in design, which came to be known as pontoon "jewelry."

\footnotetext{
${ }^{20}$ Document, "Notes on the Development," SMA; Navy Department, Bases, Vol. 1, 157-58.
} 
For use in sectional drydocks, Laycock incorporated fittings to flood and drain the pontoons as circumstances required. With the models and designs for the pontoons and jewelry complete by December 1940, BuDocks finalized blueprints and entered a contract with the Pittsburgh-Des Moines Steel Company on 18 February 1941 to fabricate several pontoon units for testing and evaluation. Lieutenant (j.g.) William B. McLean, Jr., CEC, oversaw the final development of the pontoon in Pittsburgh for BuDocks. Earlier work found a solution to the

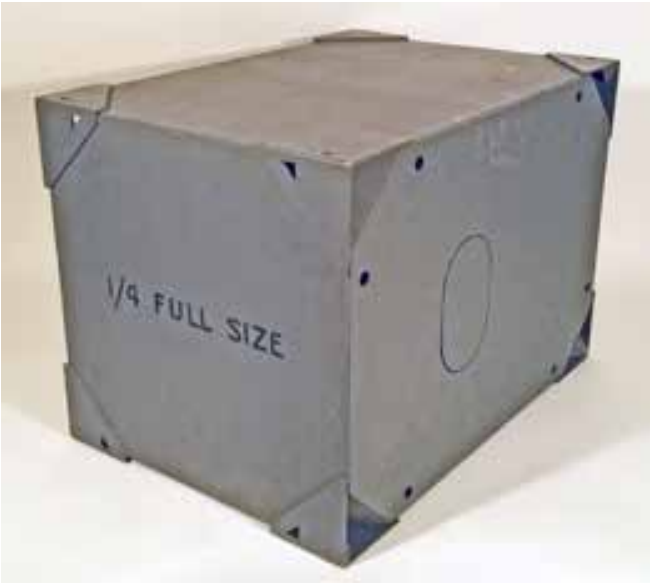

A one-quarter scale wood model of a T-6 pontoon. (National Museum of American History, Washington, DC) problem of internal stiffening for the pontoons by welding six-inch steel plates to form a T-shape and then welding these girth-wise to the pontoon interiors. The pontoon sides and bottoms used 3/16-inch plate while the decks used 5/16inch checkered plate for added strength and traction. The five-by-seven-by-fivefoot $\mathrm{T} 6$ pontoon weighed one ton with various connections adding an additional 800 pounds. They could withstand internal pressures of twenty-five pounds per square inch and individually had a net buoyancy capacity of about four tons with an ultimate deck load of twenty-five tons on any twenty inches square. Another variant, the T7, measured seven-by-seven-by-five feet with a curved section at one end of the pontoon for use as a prow on transport barges. ${ }^{21}$

In May 1941, BuDocks and Pittsburgh-Des Moines commenced testing of the pontoons. The first test used a string of eleven pontoons in a bridge configuration with a load placed on the assembly center. The string broke bearing a load of fiftyfive tons when one of the lower angles failed. The next series of tests involved assembling the pontoons into a three-by-seven barge for towing in the Ohio River. BuDocks next assembled the pontoons into a floating patrol torpedo (PT) boat drydock and seaplane ramp for testing at Neville Island, Pennsylvania. The pontoons and assemblies proved satisfactory in all tests. In the face of demand to construct Lend Lease bases in the United Kingdom, BuDocks assigned the Merritt Chapman Scott-Fuller Construction group, then engaged in construction of Naval Air Base, Quonset Point, Rhode Island, to procure, ship, and erect a Navy landing

21 Document, "Notes on the Development;" document, "The Navy Landing Pontoon," 20 February 1958, SMA; Bureau of Yards and Docks, N.L. Equipment - Assembly Manual for Pontoon Gear, Revised (Washington, DC: Department of the Navy, August 1942), i; Navy Department, Bases, Vol. 1, 158; Lewis B. Combs, "Innovation of Amphibious Warfare," The Military Engineer 36, no. 220 (February 1944): 46. 
pontoon stockpile for overseas use. In turn, BuDocks placed an order for 3,000 pontoons and accessories with Pittsburgh-Des Moines for shipment to Quonset Point for the UK bases. ${ }^{22}$

\section{The Innovator and his Idea}

Initial US Navy operations with the pontoons, however, came in the Society Islands of the South Pacific. The 1st Headquarters Construction Company, initially trained and organized for operations in Iceland in 1941, found itself redirected in January 1942 to construct and establish a fueling base at Bora Bora. An expanded and largely untrained - group of CEC officers and enlisted Seabees organized as the 1st Naval Construction Battalion under the command of Lieutenant Commander Harold M. Sylvester, CEC. The battalion hastily shipped out for Bora Bora on 27 January with the new landing pontoons from the Quonset Point stockpile among the supplies. Arriving at the island group on 17 February after sailing over 8,300 miles, the fledgling force discovered the pontoons needed to assemble lightering barges were accessible, but the all-important connecting jewelry was stored at the bottom of the cargo holds. Despite this oversight, the Seabees started digging out the required parts. Sylvester wrote Moreell the following day, remarking how his men "already made great progress in assembling our Quonset landing barges. Captain Laycock and his officers certainly produced a wonderful contribution to our advanced bases with all of their advance base gear." ${ }^{23}$ Once assembled, the pontoons performed without issue. Pontoons at Bora Bora and at other South Pacific locations would in turn be used as piers and wharves rather than mere barges, an early demonstration of the flexibility inherent in Laycock's simple but strong design. ${ }^{24}$

Sylvester left Bora Bora in mid-July 1942, returning for duty at the Mare Island Navy Yard in California. In December, his pontoon and organizational experience brought him east to Davisville, Rhode Island to organize BuDocks's Advance Base Proving Ground at Allen's Harbor. ${ }^{25}$ Previously known as the Quonset Pontoon Experimental Area, the proving ground provided the space necessary for Laycock and his fellow officers to test an array of pontoon assemblages and to train men

\footnotetext{
22 Document, "Notes on the Development;" document, "Landing Pontoon"; document, "Interview with Laycock," SMA; Navy Department, Bases, Vol. 1, 158.

23 Harold Sylvester to Ben Moreell, 18 February 1942, Harold M. Sylvester file, SMA.

24 United States Navy, Building the Navy's Bases in World War II, 196-202; Gina Nichols, "Code Name: BOBCAT - Part II," The Sextant, Naval History and Heritage Command, 3 March 2017, https://usnhistory.navylive.dodlive.mil/2017/03/03/code-name-bobcat-part-two/ (accessed 24 June 2019); Frank A. Blazich, Jr., "Confluence of War: The Battle of the Atlantic, Iceland and Seabee Origins," Seabee Magazine, 31 October 2014, https://seabeemagazine.navylive.dodlive. mil/2014/10/31/confluence-of-war-the-battle-of-the-atlantic-iceland-and-seabee-origins/ (accessed 24 June 2019).

25 Ben Moreell to George D. Wetsel, 11 August 1942; Ben Moreell to Ezra Allen, memorandum, 28 February 1944, Harold M. Sylvester file; document, "Bora Bora - Introduction,” 21 July 1944, SMA; Matthews, "Patron," 10.
} 
on the assembly and handling of the pontoons. The proving ground's work also supported Allied military endeavors, particularly for representatives from the Royal Navy. ${ }^{26}$

After the German conquest of Western Europe in 1940, the British Chiefs of Staff stood up what became known as Combined Operations Headquarters. This new joint air-sea-land organization would plan and direct offensive operations against enemy-occupied territories. Within the new command was the Inter-Services Training and Development Centre (ISTDC), which investigated and developed methods and equipment for amphibious combined operations. ${ }^{27}$ By summer 1941, the British Chiefs of Staff recognized that large scale operations on the European continent required many new assault craft and specialized vessels able to deliver men, tanks, and an array of vehicles to beaches in amphibious operations.

Following the Argentia Conference between President Roosevelt and British Prime Minister Winston Churchill in August 1941, a small three-man Admiralty delegation, the British Landing Ship Mission, came to Washington, DC in November and met with Chief of Naval Operations, Admiral Harold Stark, and other senior officials to discuss the design and construction of three such craft: a Landing Ship, Tank (LST), Landing Craft, Tank (LCT), and Landing Ship, Dock (LSD). The two nations agreed that the US Navy's Bureau of Ships would design and provide detailed plans for these three vessels. Prior to the delegation's arrival, American naval architect John C. Niedermair from the Bureau of Ships (BuShips) met with USN Captain Edward L. Cochrane on 4 November and learned of the British requirements for a large tank-carrying landing craft. Niedermair, after chewing over the British requirements, had sketched out a concept design for the LST. His refined plans had been received in England prior to the Admiralty mission where they met with immediate approval. By January 1942, BuShips had a detailed set of plans to construct the ship; on 7 September, the Dravo Corporation in Pittsburgh launched LST-1 which was commissioned on 14 December. ${ }^{28}$

\footnotetext{
26 Navy Department, Bases, Vol. 1, 156-57; Matthews, "Patron," 10.

27 History of the Combined Operations Organisation, 1940-1945 (London: Amphibious Warfare Headquarters, 1956), 10-12, 151-56.

28 Royal Commission on Awards to Inventors (RCAI), Claim of Captain T.A. Hussey, First Day, 12 March 1951, pp. 6-7, T 166/10; "The Naval Construction Department of the British Admiralty Delegation, 1941 to 1945," 30 August 1945, 12-13, ADM 281/141, National Archives, Kew, London, United Kingdom (NA-Kew); John C. Niedermair, "Designing the LST," in Assault on Normandy: First-Person Accounts from the Sea Services, ed. By Paul Stillwell (Annapolis, MD: Naval Institute Press, 1994), 154-58; John C. Niedermair, Reminiscences of John C. Niedermair (Naval Architect - Bureau of Ships), oral history by John T. Mason, Jr. (Annapolis, MD: US Naval Institute, January 1978), 225-30; Department of the Navy, Naval Historical Center, "Tank Landing Ships (LST), in Dictionary of American Naval Fighting Ships, Vol. VII (Washington, DC: GPO, 1981), 569-74; LST1, Dictionary of American Naval Fighting Ships (DANFS), Naval History and Heritage Command, https://www.history.navy.mil/research/histories/ship-histories/danfs/1/lst-1.html (accessed 26 June 2019); Larrie D. Ferreiro, "Chapter 3: Creating the American LST," draft book chapter, shared with author on 5 May 2021. The Admiralty delegation consisted of Captain Thomas A. Hussey, Commander Robin C. Todhunter, Deputy Director of Naval Equipment for Combined Operations,
} 
The British officer leading the Admiralty delegation to the US Navy was Captain Thomas A. Hussey. ${ }^{29}$ A native of Exeter, Devonshire, Hussey attended the Royal Navy College at Dartmouth from 1911 to $1914 .{ }^{30}$ At the age of 16, Midshipman Hussey entered World War I aboard battleships and saw service in the Gallipoli campaign, at the Battle of Jutland, and the surrender of the German High Seas Fleet at Scapa Flow in late 1918. Postwar, he commanded multiple destroyers until retiring as a commander in 1937. Prior to British entry into World War II, Hussey rejoined the Royal Navy in June 1939, commanding the destroyer HMS Versatile and participating in the evacuation of the Dutch government and royal family on 13 May 1940 in Operation Ordnance. That evening, three Luftwaffe aircraft bombed and strafed his ship, killing seven and wounding thirty-three sailors while shredding Hussey's monkey jacket and necessitating a tow back to England. The following month, Hussey received orders to join Combined Operations Command, admitting he "had no knowledge of what it was all about." Initially he served as naval assistant to the commandant of ISTDC. In November 1940, Hussey became

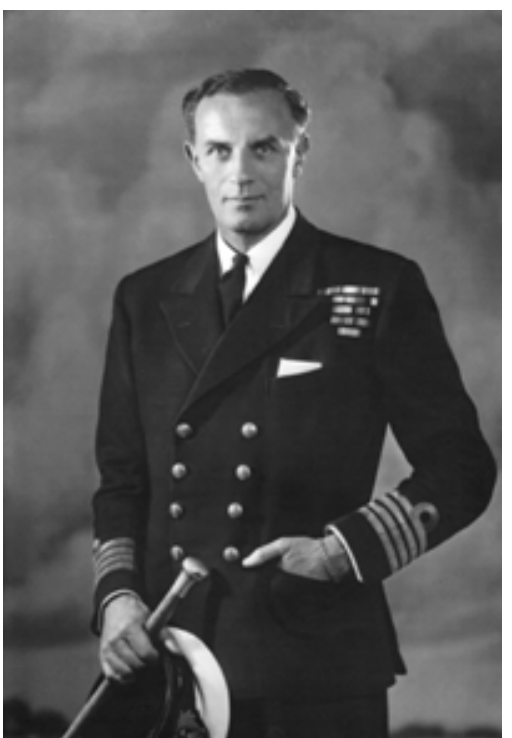

Captain Thomas Andrew Hussey, RN, ca. 1946. (Image provided by Andrew Hussey, Manston, UK)
ISTDC commandant with acting rank of captain. ${ }^{31}$

During a free week prior to the attack on Pearl Harbor, Hussey went to New Orleans and visited Higgins Industries. There he saw the new Higgins boats (Landing Craft, Vehicle, Personnel, LCVP), but the British representative at the facility told Hussey "Why do you not go up to Narragansett Bay [Rhode Island] where the Navy Department have some rather ingenious equipment called Naval N.L. equipment, using which they can construct barges and piers very quickly." 32 Hussey made the trip north, and the enormous stocks of pontoons impressed him greatly, although he believed the Americans at the time had "no intention of ever using it for combined operations." Upon his return to England in January 1942, Hussey reported

and Mr. Rowland Baker, Royal Corps of Naval Constructors. Bernard Fergusson, The Watery Maze: The Story of Combine Operations (New York: Holt, Rinehart and Winston, 1961), 112.

29 Russell Weigley, The American Way of War: A History of United States Military Strategy and Policy (Bloomington, IN: Indiana University Press, 1973), 263; Fergusson, Maze, 112-18.

30 Previously known as HMS Britannia and today as Britannia Royal Naval College, this is the naval academy of the United Kingdom.

31 RCAI, Hussey, 2, T 166/10; Roger Keyes to Second Sea Lord, 21 November 1940, DEFE 2/813, NA-Kew; naval service history of Thomas Andrew Hussey, CBE; biography, "Thomas Andrew Hussey (1898-1980)," provided to the author by Andrew Hussey, 21 October 2019.

32 RCAI, Hussey, 7, T 166/10, NA-Kew. 
the pontoon technology to the Chief of Combined Operations and the Admiralty, but neither thought the pontoons useful, with naval constructor Rowland Baker remarking "whatever they [Americans] can build of them we can build much better in one piece." 33 Beyond acquiring photographs and accounts of them, no actual experimentation with the American pontoons occurred in England. ${ }^{34}$ By August, however, the British Admiralty Delegation (BAD) in Washington reported to the Admiralty back in London of further developments with the lighterage pontoons: "we are impressed with the ease with which these pontoons can be shipped and assembled wherever required and feel ... they would be valuable for many landing [o]perations...." 35

This positive assessment of the pontoons would prove valuable to Hussey. In April 1942, the Chief of Combined Operations, Commodore Louis Mountbatten, reorganized ISTDC to coordinate and control experiments and developments in combined operations. Hussey moved to London to join Mountbatten's staff with the new title of Coordinator of Experiments and Developments, later changed to Director of Experiments and Operational Requirements. In this position, Hussey oversaw the Combined Operations Experimental Establishment (COXE), tasked with investigating problems likely to be encountered with amphibious operations during European invasions, particularly in the landing of vehicles and supplies. Among other responsibilities, Hussey was directly responsible to Mountbatten for the development of all special craft and equipment required for combined operations ${ }^{36}$

Following the successful Allied landings in North Africa (Operation Torch), Hussey learned of planning for the next operation - the invasion of Sicily (eventually named Operation Husky). His examination of sounding charts of the island revealed gently sloping sea floors for all the planned invasion beaches. These gentle slopes would cause the LSTs to ground several hundred feet from shoreline in water six feet deep. Waterproofed vehicles could only safely wade ashore beginning from no farther than 300 feet out from the beach. Alarmed, Hussey brought the issue before Mountbatten, who recommended the captain assemble a team of technical experts to find a solution. Following discussion in mid-December between the best amphibious technical experts at Combined Operations, the only known option involved use of the US Army Corps of Engineers' treadway bridge

\footnotetext{
33 RCAI, Hussey, 10, T 166/10, NA-Kew. It is not clear if Baker accompanied Hussey to see the naval pontoon equipment in person. David K. Brown, "Sir Rowland Baker, RCNC," Warship (1995): $145-47$.

34 Loben E.H. Maund, Assault from the Sea (London: Methuen and Co. Ltd., 1949), 82-83; Guy Hartcup, The Challenge of War: Britain's Scientific and Engineering Contributions to World War II (New York: Taplinger Pub. Co., 1970), 214, 220; Chief of Combined Operations to Engineer in Chief, War Office, subject: United States Naval Pontoon Landing Equipment, 24 July 1942, DEFE 2/794, NA-Kew.

35 Message from BAD Washington to Admiralty, "Piers," 12 August 1942, DEFE 2/58, NA-Kew.

36 Combined Operations Organisation, 156-57; Ian Speller, The Role of Amphibious Warfare in British Defence Policy, 1945-1946 (New York: Palgrave, 2001), 37-38; Fergusson, Maze, 125.
} 
used in the North Africa landings in November. Designed for crossing streams, the structure used collapsible pneumatic floats and steel beam treadways placed overtop to function as either a floating or fixed bridge. The structure, however, had proven unstable at moving tanks from ship to shore, required over an hour to assemble in calm seas, and the British lacked the ability to manufacture the equipment. Furthermore, the bridge had to be stowed on the tank deck of an LST, using up valuable space on even more valuable ships. ${ }^{37}$

On 9 January 1943, Hussey received a directive to solve the causeway problem. When he broached the issue of constructing a 300-foot-long causeway with naval constructor Baker, Hussey learned there was no shipyard capacity available. He then recalled the American pontoon equipment he saw back in December 1941. On 21 February 1943, he presented Mountbatten with an idea of a floating prefabricated roadway or causeway using American pontoons. These, he explained, could be towed behind the LSTs to the invasion beaches until positioned so that forward momentum drove the causeways ashore. Once in place the causeways could be secured to the LST ramp so vehicles could drive off the ship and up to the beach in the dry. While some of his staffed doubted the idea, Mountbatten saw the viability of Hussey's proposal. He ordered the captain to Washington to press for construction of a prototype and operational trials between the treadway bridge and the navy pontoon causeway. Mountbatten wired Husky's overall commander, General Dwight D. Eisenhower, to explain the problem of the beach slopes and the critical importance of Hussey's mission. The matter required expediency if all the necessary equipment were to arrive in time for the planned D-Day of 10 July. ${ }^{38}$

Unfortunately, upon arrival in Washington on 4 March, Hussey found no effort underway for conducting trials. He met with Admiral Sir Percy Noble, RN, and Field Marshal Sir John Dill of the British Joint Staff Mission to emphasize the urgent need for a solution, explaining "that the necessary gear should be shipped in all L.S.T. within 21 days, or the operation was 'off'." 39 The senior British officers agreed to bring the matter before the Combined Chiefs of Staff. Hussey met on

37 Alfred M. Beck, Abe Bortz, Charles W. Lynch, Lida Mayo, and Ralph F. Weld, The Corps of Engineers: The War Against Germany (Washington, DC: United States Army, Center of Military History, 1985), 75-76; War Department, Technical Manual 5-272: Steel Treadway Bridge Equipage (Washington, DC: GPO, 10 July 1942), 1; Blanche D. Coll, Jean E. Keith, and Herbert H. Rosenthal, The Corps of Engineers: Troops and Equipment (Washington, DC: United States Army, Center of Military History, 1958), 486-93; RCAI, Hussey, 11-12, T 166/10; Minutes of Meeting Held at C.O.H.Q. on 12 December 1942 to Discuss Equipment for Bridging the Water Gap Between the Ramps of L.S.T. Mks. I and II and the Shore, on Flat Beaches, 15 December 1942; Statement by Vice Admiral Earl Mountbatten, K.G., etc., T166/126/5; cable, commanding officer, HMS Bachaquero to Secretary of the Admiralty, 23 December 1942, WO 203/2992, NA-Kew.

38 RCAI, Hussey, 13-14, T 166/10; Louis Mountbatten to Thomas A. Hussey, naval cypher T.O.O. 1808/24/2, 24 February 1943; Louis Mountbatten to Dwight D. Eisenhower, memorandum S.R. 1057/43, 26 February 1943 and attachment, "Memorandum on the Possible Methods of Disembarking A.F.V. and M.T. from L.S.T. on Flat Beaches," 23 February 1943, DEFE 2/1007, NA-Kew.

39 Extract from War Diary Dated Tuesday, 6 April 1943, Bridging the Gap, DEFE 2/1507, NA-Kew. Emphasis in original. 
the eighth in the Navy Department with Rear Admiral Charles Cooke, Assistant Chief of Staff (Plans) to Admiral Ernest J. King, Chief of Naval Operations and Commander-in-Chief, United States Fleet. In Hussey's words, Cooke "was very angry indeed. He said he had never heard of anything so monstrous in his life, that they had been looking at the plans of Sicily and there was definitely no need for qualms over anything." Cooke further told Hussey how "the equipment which I had described to him would not work, and in any case he had never heard of American N.L. pontoon equipment." Hussey promised the admiral the pontoon equipment did exist, and recommended Cooke telephone Captain Laycock at BuDocks to help explain the pontoon equipment to him. ${ }^{40}$

Over the telephone, Laycock assured the admiral that the Navy had plenty of pontoons to spare. He recommended Cooke and Hussey meet with him, and together with Rear Admiral William Purnell, Deputy Chief of Naval Operations for Materiel, the group watched a film of the pontoon equipment being assembled into three basic structures. Cooke asked Laycock if Hussey's proposal could work, to which the CEC officer replied it could. Cooke authorized construction of a prototype but refused a trial on grounds he had no LSTs to spare. Undaunted, Hussey secured the LSTs the following day after meeting with Rear Admiral Alan Kirk, Commander, Amphibious Force, Atlantic Fleet. From 1939-1941, Kirk had served in London as the American naval attaché and had previously worked with Hussey. This past connection aided the British captain as he explained the trial problem in detail to friendly, receptive ears. Kirk agreed to loan two LSTs for the trials, and placed Lieutenant Commander William F. Royall, his officer-in-charge of Research and Development, under orders to command the ships and work with Hussey to carry out the trials. ${ }^{41}$

With the matter seemingly resolved, Hussey learned that same day, 9 March, of yet more problems. The Navy evidently resented the Army using the pontoons, i.e., Navy equipment, and informed the sister service that their treadway bridge was not required for the trials. Hussey defused the situation after informing General Sir Richard McCreery, who met with General Brehon B. Somerville, commanding Army Service Forces, of the criticality of the trials. ${ }^{42}$ Admiral Noble wrote to Admiral King as well, contending that since there appeared to be an insufficient quantity of naval landing pontoon equipment then available in the United States, "it seems likely that the solution may well be a combination" of the Navy pontoons with the Army treadway bridge. "From every point of view, it seems that the two

40 RCAI, Hussey, 14-15, T 166/10, NA-Kew.

41 David Kohnen, "Persistent - Alan Goodrich Kirk (1888-1963)," in Nineteen-Gun Salute: Case Studies of Operational, Strategic, and Diplomatic Naval Leadership during the 20th and Early 21st Centuries, ed. John B. Hattendorf and Bruce A. Elleman (Newport, RI: Naval War College Press, 2010), 77-78, 83-84; RCAI, Hussey, 14-16, T 166/10, NA-Kew; statement by William F. Royall regarding the development of N.L. pontoons as causeways to bridge the water gap between grounded L.S.T. and the beach, 17 November 1948, SMA.

42 John Knox to Louis Mountbatten, "Unloading L.S.T. on Shallow Beaches," 9 March 1943, DEFE 2/1007, NA-Kew. 


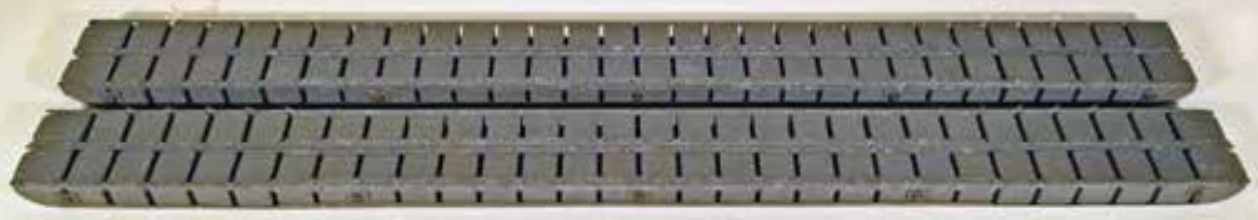

Wood scale models of two 2x30 pontoon causeway sections. (National Museum of American History, Washington, DC)

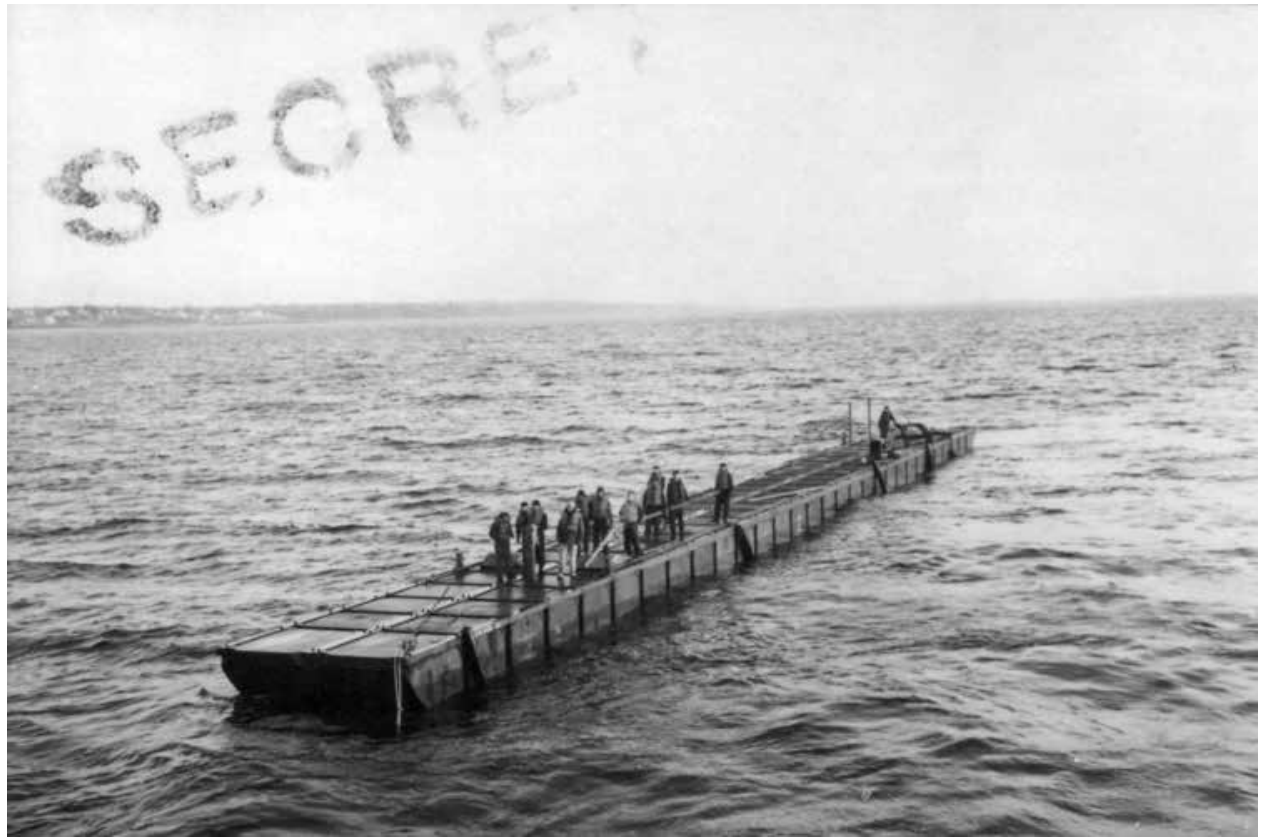

An assembled 2X30 pontoon causeway section. (Image provided by Andrew Hussey, Manston, UK)

systems should be tried out at the same place," explained Noble, adding "I should be most grateful if you would use your good offices to allow the Army equipment to be tried at the same time and place as the pontoon equipment." 43 The Navy's opposition ceased.

As Hussey gathered resources and support, Laycock met with his assistant, Captain John Knox, RN, to discuss Hussey's idea for a large floating barge or causeway. Hussey had proposed a 350-foot-long structure, but Laycock explained to Knox that the existing pontoon material made the barge impractical, as the present maximum length of a pontoon string measured 105 feet in length. Recognizing the difficulties of handling four of these long craft together in rough seas, Laycock considered this an impossible seamanship problem.

With Knox assuring Laycock the Royal Navy would welcome a solution, the American officer opted for a compromise. Laycock computed a length of 175 feet

43 Percy Noble to Ernest J. King, N.O. 105/43, 8 March 1943, DEFE 2/1007, NA-Kew. 
for a causeway with sufficient longitudinal stability to stay afloat when a tank was run across from end to end. By using two of these causeways overlapped (akin to a slide rule), a maximum length of 325 feet could be safely constructed and thus bridge the ship to shore problem. Laycock's resulting design produced a two-bythirty pontoon, 175-foot-long causeway. The continuous steel angle in the assembly used two 35-foot-long end sections of standard six-by-six-by-three eighths-inch steel angles with three center sections of eight-by-eight-by-three eighths-inch steel angles producing a strong but flexible structure. ${ }^{44}$ These larger assembly angles at the core of the string carried the increasing load of the longer box girder.

Hussey agreed with Laycock's solution and offered additional technical details which figured into the plans. When Hussey arrived at BuDock's Advance Base Proving Ground at Davisville, Rhode Island on 12 March, work was underway on assembling the causeways. Laycock could not personally attend the trials but telephoned construction instructions to the proving ground director, now Commander Sylvester, CEC, placing him at Hussey's disposal to work out all details. Hussey himself went around taking soundings in Narragansett Bay until he found a beach which he thought resembled those found in Sicily. ${ }^{45}$ Two days later, Hussey received approval for his demonstration. In a scant four days, Sylvester oversaw production of special fittings and construction of a pair of causeways for the planned demonstration. Lieutenant Commander Royall worked with the Seabees to develop the seamanship technique for placing the causeways and training the LST crews for the critical trial. ${ }^{46}$

On 18 March, Hussey's trial with Laycock's new creation commenced in the waters of Narragansett Bay. LST-348 approached the shore carrying two M7 105mm self-propelled howitzers and towing alongside two 175-foot pontoon causeway sections connected end to end. On board were a causeway crew of twenty Seabees, a warrant officer, and a CEC officer. Just prior to the LST grounding after dropping her anchor, the causeway was slipped, and forward momentum drove the causeway up on the beach. Within eight minutes, the Seabees maneuvered the causeway into alignment with the LST bow ramp, flooded the individual pontoons, and anchored the causeway on the seafloor. The first M7 idled on the beach sixteen and a half minutes after the LST grounded. For the next trial, LST-349 came ashore and grounded. Four officers and thirty-six soldiers from the Army Corps of Engineers began to assemble a treadway bridge until 360 feet of the structure linked LST

\footnotetext{
44 Document, "Landing Pontoon"; John N. Laycock, "To Whom it May Concern: Pontoon Causeways in Sicilian Invasion," undated (1949); John N. Laycock, "To Whom it May Concern: Long Pontoon Causeways and Rhino Ferries," 20 September 1949, SMA; Fergusson, Maze, 232. Some sources list the causeway length as 175 feet. The exact length of the causeway section is 176 feet, eleven inches long by fourteen feet, three and three quarters inches wide, and five feet, two and three-eighths inches high. Bureau of Yards and Docks, Pontoon Gear Manual: Revision of March 1944 (Washington, DC: Department of the Navy, 1944), 6, 102.

45 Document, "Landing Pontoon"; Laycock, "Sicilian Invasion"; Laycock, "Causeways and Rhino Ferries," SMA; Fergusson, Maze, 232; RCAI, Hussey, 16, T 166/10, NA-Kew.

46 Laycock, "Sicilian Invasion," SMA; William B. Huie, Can Do!, 109-12; Matthews, "Patron," 11.
} 


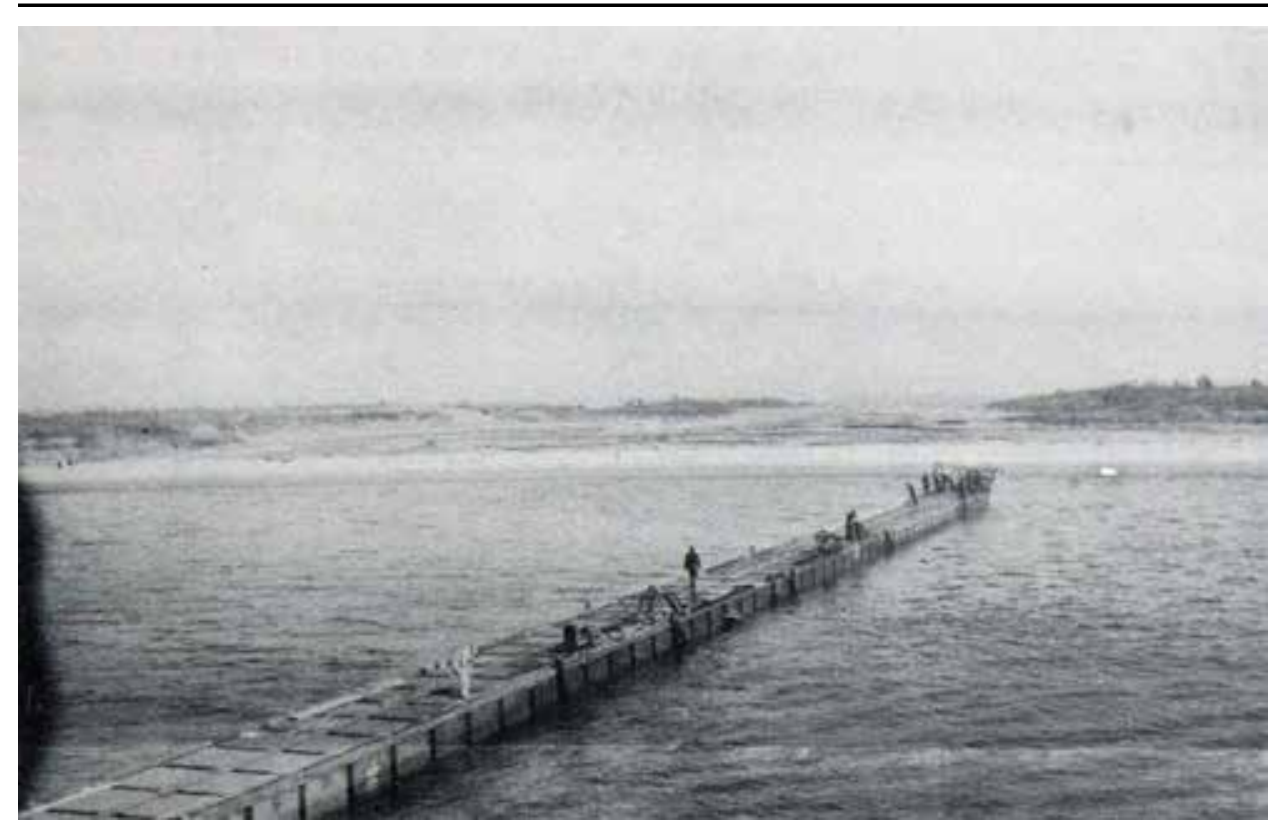

Assembled pontoon causeway at Narragansett Bay, 18 March 1943. (Bureau of Yards and Docks, Handbook on the Use of N.L. Pontoon Causeways and Army Steel Treadway Pontoon Bridges for Ship-to-Shore Connections Between LST Ships and a Gently Sloping Beach (Washington, DC: Navy Department, April 1943), 30)

to shore. After forty-five minutes, the two M7s from the first test drove over the treadway bridge and into the LST. The demonstration convinced senior planners that amphibious landings could work with either system, but the naval landing pontoons proved the superior design for the task at hand. The following day the Navy Department agreed to supply pontoon equipment for the invasion. ${ }^{47}$

Within weeks pontoons began to multiply in North Africa and two specialized Seabee units, the 1005th and 1006th Construction Battalion Detachments (CBD), received orders to ship out from Bayonne, New Jersey to Arzew, Algeria. Arriving in early May 1943, CBD 1005 set up headquarters in Arzew while CBD 1006 moved to Bizerte. CBD 1005 commenced assembling pontoons and pontoon causeways with three shifts working twenty-four hours a day. Meanwhile, CBD 1006 engaged in training and experimenting with launching and beaching of the causeways. While perfecting the landing of the causeways, Rear Admiral Richard L. Conolly, Commander, Landing Craft and Bases, Northwest African Waters,

47 Laycock, "Sicilian Invasion," SMA; William B. Huie, Can Do! The Story of the Seabees (Annapolis, MD: Naval Institute Press, 1997), 109-12; Matthews, "Patron," 11; Niedermair, Reminiscences, 235-36; RCAI, Hussey, 12 March 1951, pgs. 6-7, T 166/10; John Knox to Louis Mountbatten, 24 March 1943; document, "L.S.T. Demonstration at Narragansett Bay, Rhode Island, 18 March 1943 - Bridging the Gap,” DEFE 2/1130; Godfrey E. Wildman-Lushington to Secretary to the First Sea Lord with attachment, 16 April 1943, DEFE 2/1129; extract from War Diary dated Tuesday, 6 April 1943, Bridging the Gap, DEFE 2/1507, NA-Kew. 


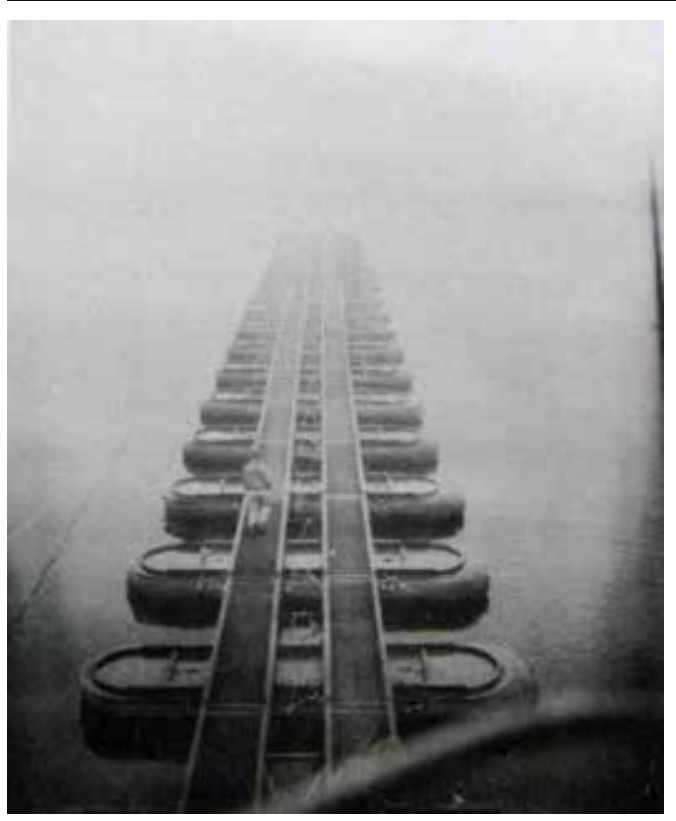

Assembled treadway bridge at Narragansett Bay, 18 March 1943. (source as previous image)

suggested carrying the causeways on the sides of LSTs rather than towing them. The US Navy subsequently worked out a means to side-carry and launch the causeways prior to landing, saving considerable time in the movement of the American invasion force. ${ }^{48}$

In the early morning hours of 10 July 1943, the amphibious invasion of Sicily commenced. Ten LSTs side-carried causeways while six additional causeways were towed to the assault beaches for the US Seventh Army landing along the Gulf of Gela. The causeways arrived without incident, each manned by platoons of two officers and thirtyfour enlisted men drawn from the 54th Naval Construction Battalion (NCB), and CBD 1005 and 1006. Despite five-foot seas, the causeways worked brilliantly unloading LSTs. In twenty-three days of round-the-clock shifts the Seabees unloaded over 10,000 vehicles on the causeways. ${ }^{49}$ For the British Eighth Army's landings at the Gulf of Noto, LSTs towed all of the causeways to the beaches; despite limited training and problems with assembly the causeways proved a valuable asset. ${ }^{50}$ Captain George R.G. Allen, RN, Senior Naval Landing Officer (How Sector), Acid Centre, wrote the causeways "proved very successful on the whole and should now be regarded as an integral part of the equipment of a group of L.S.T.'s." ${ }^{51}$ As recalled in an article in the Saturday Evening Post

48 Navy Department, Bases, Vol. 2, 80; A.C. Church to Ben Moreell, memorandum, subject: Report to the Bureau from 23 March 1943 to 1 June 1943, 7 June 1943; T.J. Davey to John J. Manning, memorandum, subject: Captain T.A. Hussey, CBE, R.N. (Ret.), 18 April 1949; Naval Construction Detachment 1005 Historical Information packet; Naval Construction Battalion Detachment 1006 Historical Information packet, SMA; Huie, Can Do!, 112-13.

49 Navy Department, Bases, Vol. 2, 85-87; Huie, Can Do!, 112-13.

50 Document, "Memorandum on use of causeways in Sicily and Italy by Party Chain as told to Lt. David Knox (CEC) USNR at Madras, India," SMA. Exactly how many causeways (and where) the British used them in Husky remains undetermined, with at least 25 constructed according to the cited memorandum.

51 George R.G. Allen to Thomas Troubridge, 20 August 1943, Appendix VI, Enclosure No. II to Thomas Troubridge to Bertram Ramsay, Report of Proceedings - Operation "Husky", Naval Commander Force "A", 10 August 1943, Reel A1799, p. 585, Commander-in-Chief, Mediterranean, Report of the Operations for the Invasion of Sicily, July-August 1943, World War II War Diaries, Other Operational Records and Histories (WWII-WD), Records of the Office of the Chief of Naval 
by Lieutenant (jg) William B. Huie, when British General Sir Bernard Law Montgomery stepped from his landing craft onto a causeway, no less than Vice Admiral Lord Louis Mountbatten corrected a photographer that "the general is not setting foot on Sicily. He is setting foot on one of these miraculous American pontoons." 52 In a letter to Moreell, Conolly remarked, "It is my opinion that the HUSKY Operation could not have been accomplished so successfully without the pontoon causeways, and that unloading of LSTs over causeways is the most rapid method developed to date for use on shallow beaches." 53

\section{Enter the Rhinos}

Mountbatten's correction proved no idle comment as he enthusiastically embraced usage of the landing pontoons. The admiral actively participated in the Inter-Allied Conference held in Quebec, codenamed Quadrant, from 14-24 August 1943 during which civilian and military leaders approved an outline plan from British Lieutenant General Frederick E. Morgan, Chief of Staff to the Supreme Allied Commander (COSSAC) for a cross-channel invasion of the coast of Normandy east of the Cotentin Peninsula in France. Discussions at Quadrant touched upon the obvious problem of logistics for this operation, codenamed Overlord. The objective of the naval landings, codenamed Neptune, would carry out an operation from the United Kingdom to secure a lodgement on the European continent, with sufficient port facilities to maintain a force of twenty-six to thirty divisions, augmented by additional formations from three to five divisions a month. ${ }^{54}$

Planners had to develop the means to out-supply the German forces fighting to push the invasion force back into the sea. Overlord's overall success required facilities able to handle 6,000 tons of supplies per day by 10-11 June, then 9,000 tons daily by $16-18$ June, rising to 12,000 tons by $22-24$ June. ${ }^{55}$ Recognizing the need for port facilities, but also the challenge of seizing the port at Cherbourg, British planners hatched on the scheme of building an artificial harbor able to discharge approximately 6,000 tons daily. ${ }^{56}$ While in Quebec, Mountbatten had his

Operations, Record Group 38 (RG38), National Archives and Records Administration, College Park, MD (NARA).

52 William B. Huie, "Slickest Trick of the War," Legislative and Information Division, Bureau of Yards and Docks, Navy Department, 29 April 1944, SMA; Henry K. Hewitt, Action Report, Western Naval Task Force, The Sicilian Campaign - Operation "Husky" July-August 1943, pp. 51-53, 101, https://www.history.navy.mil/research/library/online-reading-room/title-list-alphabetically/s/thesicilian-campaign-operation-husky.html (accessed 27 June 2019).

53 Richard L. Conolly to Ben Moreell, memorandum, subject: Performance of Pontoon Causeways, 27 July 1943, DEFE 2/1130, NA-Kew.

54 Operation Neptune - Naval Orders, ON 1 - General Outline of the Operation, Reel A1805, p. 8, Allied Naval Commander-in-Chief, Expeditionary Force, Naval Operations Orders for the Invasion of Normandy, France, RG38, NARA.

55 Roland G. Ruppenthal, The European Theater of Operations: Logistical Support of the Armies, Vol. 1: May 1941 - September 1944 (Washington, DC: Center of Military History, 1994), 271.

56 Ruppenthal, Logistical, 272. 
science advisor, Professor John D. Bernal, demonstrate the concept of constructing an artificial breakwater, the foundational component of an artificial harbor, in a hotel bathroom to various senior officials, replicating an experiment conducted on the voyage to Canada. Using a bathtub aboard the liner Queen Mary to simulate the ocean, Bernal floated paper boats at one end while Hussey, with a rolled-up newspaper, agitated the water opposite of him. The ripples and waves naturally tossed the little boats about. Bernal next placed a loofah in the middle of the tub's water, between Hussey and the boats. Functioning as a breakwater, the loofah

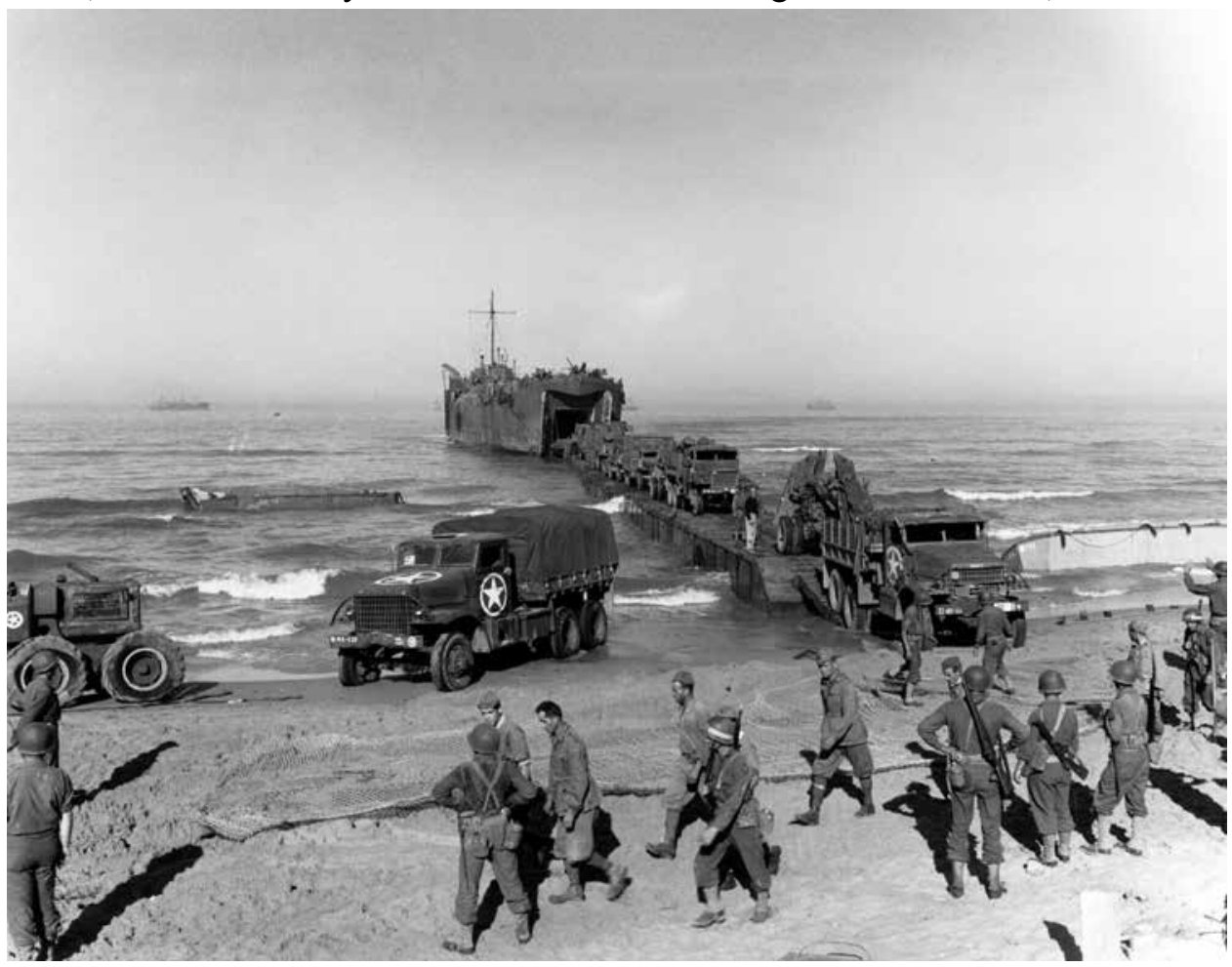

USS LST-336 unloads trucks over a pontoon causeway, near Gela, Sicily, July 1943. (National Archives and Records Administration)

absorbed the energy of Hussey's waves and the paper boats came to rest. The simple experiment won over doubters and the artificial harbors thereafter entered the Overlord plans. ${ }^{57}$

COSSAC needed two such harbors, codenamed Mulberry, to supply and reinforce the allied forces at five invasion beaches codenamed Utah, Omaha,

57 Craig L. Symonds, Operation Neptune: The D-Day Landings and the Allied Invasion of Europe (New York: Oxford University Press, 2016), 119-21, 206-08; Combined Chiefs of Staff, Quadrant Conference August 1943 - Papers and Minutes of Meetings (Washington, DC: Office, US Secretary, Office of the Combined Chiefs of Staff, 1943), 117-20, reprinted in Joint History Office, Joint Chiefs of Staff, Washington, DC; Fergusson, Maze, 285-87; Michael Harrison, Mulberry: The Return in Triumph (London: W.H. Allen, 1965), 169-70. 
Gold, Juno, and Sword. Once constructed and operational by 18 June, Mulberry A off the American beach Omaha near St. Laurant-sur-Mer, and Mulberry B off the British Gold beach near Arromanches, could handle the daily landing of 5,000 and 7,000 tons of materiel, respectively. ${ }^{58}$ Before then, planners foresaw Omaha and Utah beaches handling 10,200 tons and 5,700 tons of supplies daily by 16 June. ${ }^{59}$ Until actively unloading ships, another method of landing supplies on the Normandy invasion beaches had to be found. Estimates of the necessary supplies for the first 90 days numbered 12,000 tons of supplies and approximately 2,500 vehicles daily. ${ }^{60}$

Coastal geography again complicated landing supplies on the beaches. In Hussey's words, "it seemed to me the beaches [for the Normandy landings] were far flatter than anything we had to tackle before." flat sandy beaches, with gentle, nearly flat slopes varying up to $1: 150$ feet and a tidal range of twenty-one feet, with a high-water duration of three hours and a tidal current of three knots. At low tide with water at a depth of twelve to eighteen feet, a ship would find itself grounded over half a mile from shore. Liberty ships requiring water depths of at least twenty-eight feet would find themselves grounding at 4,000 feet from shore. LSTs seemed the logical choice to land supplies but the Normandy tidal range, coupled with long, flat beaches risked valuable ships being stranded and "dried out" for hours, large inviting targets vulnerable to enemy artillery or air attack. ${ }^{62}$

While Laycock, Hussey, and Royall worked on the causeways for Husky they also began examining problems with the invasion of France. Laycock and Royall benefited from Hussey's position as the Royal Navy's advance representation on the COSSAC planning for Overlord. This gave the Americans added time before the Quadrant conference to find solutions to bridge the Normandy tidal range and the ship-to-shore problem, particularly the problem of the period from D-Day to 18 June 1944 when the Mulberries would be operational. While taking his morning bath in late June 1943, Hussey happened upon another solution to bridging the gap. He envisioned a large self-propelled shallow draught barge with a ramp to unload vehicles at one end and a ramp at the other end to accept an LST ramp. Hussey wanted these barges to be large enough to carry half the load of an LST in one

\footnotetext{
58 Guy Hartcup, Code Name Mulberry: The Planning, Building and Operation of the Normandy Harbours (Barnsley, South Yorkshire, UK: Pen and Sword Military, 2014), 18-22; Symonds, Neptune, 318-19; William B. Huie, From Omaha to Okinawa: The Story of the Seabees (Annapolis, MD: Naval Institute Press, 1999), 178-79; Alfred Stanford, Force Mulberry: The Planning and Installation of the Artificial Harbor off US Normandy Beaches in World War II (New York: William Morrow and Co., 1951), 33; Ruppenthal, Logistical, 278.

59 Ruppenthal, Logistical, 297, 416.

60 Navy Department, Bases, Vol. 2, 99.

${ }_{61}$ RCAI, Hussey, 22, T 166/10, NA-Kew.

62 Navy Department, Bases, Vol. 2, 99-100; Stanford, Mulberry, 66-67; Huie, Okinawa, 168-73, 181-82; RCAI, Hussey, 22, T 166/10, NA-Kew.
} 


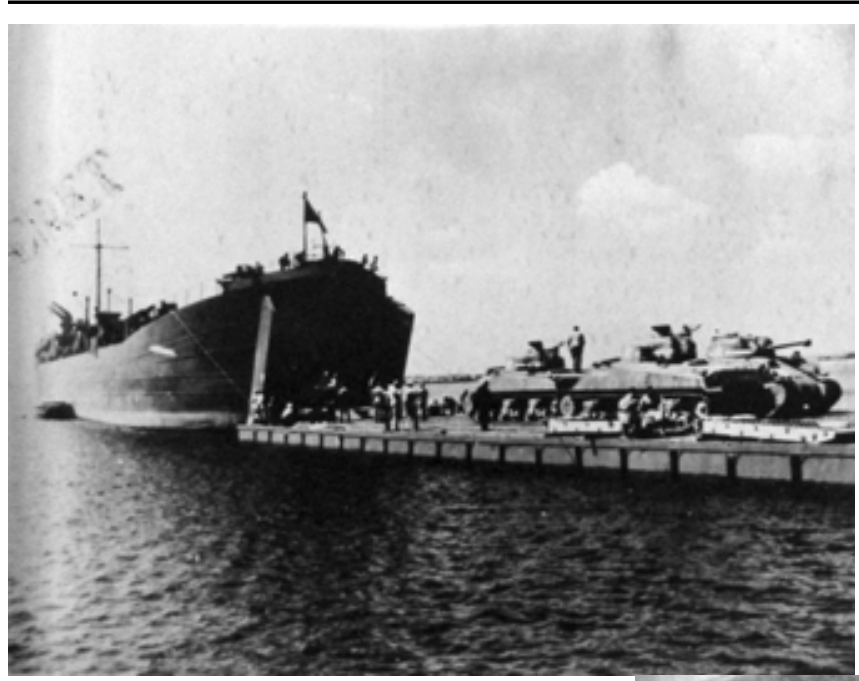

Rhino ferry prototype receiving armored vehicles, 29 August 1943. (DEFE 2/1063, National Archives, Kew, London, United Kingdom)

LST deck-load of armor vehicles on prototype rhino ferry, 29 August 1943. (DEFE 2/1063, National Archives, Kew, London, United Kingdom)

Line drawing of the original configuration of a rhino ferry, ca. September-October 1943. (DEFE 2/1010, National Archives, Kew, London, United Kingdom)
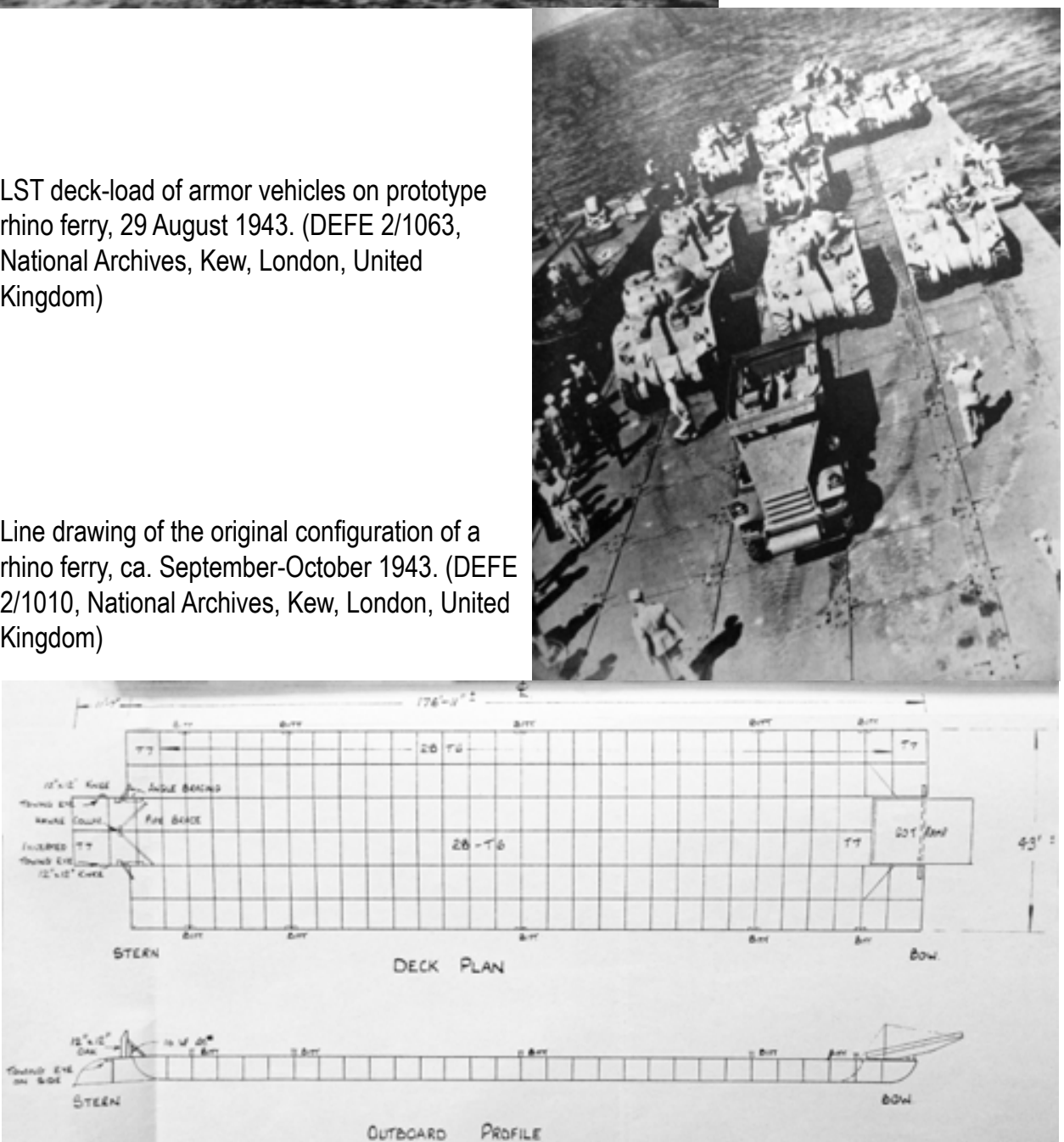
trip. ${ }^{63}$ Lightering barges provided the logical means to unload LSTs and expedite the movement of men and vehicles ashore. These would complement the massive Mulberry harbor floating piers and pierheads and, as Laycock noted, "the hazards of keeping all eggs in one basket were too severe" to risk everything on the artificial harbors alone. ${ }^{64}$

After working out a detailed description of his proposal, Hussey shared it with Mountbatten prior to the Rattle Conference of 28 June - 2 July. During the proceedings, planners discussed the problem of bridging the water gap and weighed options from wading to piers to drying out and ferries. Hussey shared his barge idea among the allied conference attendees, who agreed, if it was possible to design and build such a craft able to take a complete deck load of an LST, to proceed with its development. ${ }^{65}$ On 3 July, Combined Operations Headquarters messaged BAD Washington requesting experiments be conducted using pontoon equipment, "formed to ferry entire deck load of LST from ship to beach on first trip and upper deck load on second," and to keep Admiral Stark, Commander US Naval Forces in European Waters advised. ${ }^{66}$

The pontoon causeways developed for Sicily had proven to be the "universal solution." With little delay, Laycock experimented with using the two-by-thirty causeway strings to construct a six-by-thirty pontoon barge. Measuring 176 feet long by forty-three feet wide, the barge could move 500 tons of cargo with a draft of four feet and freeboard of one foot. Able to carry thirty to forty vehicles, the barge was large enough to unload an entire LST in two trips. By 10 July, BAD Washington reported to London that trials were underway at Davisville on propulsion units fitted to Laycock's barge. ${ }^{67}$ Two days later, Stark requested for King to hold full preliminary trials of the barge with an LST, including towing, handling, and propulsion, only to be informed that the Navy Department could not spare a single LST for a month. ${ }^{68}$ Within two weeks, the British received notice that an LST would be available in the third week of August for trials with the pontoon barge, and Hussey received orders to proceed to the United States to attend the barge trials. ${ }^{6}$ At month's end, Chief of Staff at Combined Operations, Major

\footnotetext{
63 H.F. Langley, "Rhino Ferries," 15 February 1951, T166/126/5, NA-Kew.

64 John N. Laycock, "Rhino Ferries in Normandy Invasion," 10 March 1949, SMA.

${ }_{65}$ RCAI, Hussey, 23, T 166/10; Thomas Andrew Hussey, "'Rattle' - Bridging the Water Gap,” 22 June 1943, WO 203/2992, NA-Kew.

66 USNO to Thomas A. Hussey, memorandum, 7 July 1943, DEFE 2/1063, NA-Kew.

67 Naval Cypher from BAD Washington to Admiralty (London), 10 July 1943; John N. Laycock to Ernest J. King, memorandum, subject: 6x30 NL Pontoon Rhino Barge for Unloading LST - Technical Report of Tests, 23 September 1943, DEFE 2/1063, NA-Kew. Laycock's cited memorandum reported barge capacity as 300 long tons with a mean draft of three feet, two inches. BuDocks' listed the sixby-thirty barge capacity as 500 tons with a loaded draft of forty-eight inches. BuDocks, Pontoon Gear Manual: Revision of March 1944, 8.

68 Naval cypher from Chief, Combined Operations to BAD Washington, 12 July 1943; naval cypher from BAD Washington to Admiralty (London), 17 July 1943, DEFE 2/1063, NA-Kew.

69 Naval cypher from Chief, Combined Operations to BAD Washington, 22 July 1943, DEFE 2/1063, NA-Kew.
} 


\begin{tabular}{|l|r|l|l|r|}
\hline Craft & Number & Purpose & Dimensions & Pontoons \\
\hline Causeway & 56 & Piers for LCTs and small craft & $175 \times 14 \mathrm{ft}$ & 2,800 \\
\hline Floating Drydock & 11 & $\begin{array}{l}\text { Service landing craft } \\
\text { maintenance and repair needs }\end{array}$ & 475 -ton capacity & 3,014 \\
\hline Rhino Ferry & 55 & Offload LSTs; later Liberty ships & $175 \times 45 \mathrm{ft}$ & 11,880 \\
\hline Other & & Small assemblies as required & & 8,778 \\
\hline $\begin{array}{l}\text { Total Pontoons } \\
\text { (T6 and T7) }\end{array}$ & & & & 26,472 \\
\hline
\end{tabular}

Table 1. Initial naval landing pontoon requirements for Overlord.

General Godfrey E. Wildman-Lushington, ordered Hussey to consider the largest size self-propelled raft which could be used to disembark tanks and vehicles from an LST to shore, "bearing in mind that the pontoon may have to be handled by semi-trained sailors or soldiers and that it will have to be capable of being towed by an L.S.T. at about 10 knots." 70

With trials to proceed, the experimental lighter barge itself needed additional modification to connect or "marry" up with the LST. Laycock turned to Sylvester who worked with the senior officers to develop the fittings and the techniques for marrying operations. Through the guidance of Hussey, the men fitted the barge with a large sixty-ton ramp and Sylvester had one constructed for tests in Narragansett Bay. ${ }^{71}$ Sylvester mounted two massive outboard motors, developed by Murray and Tregurtha, Inc. of Quincy, Massachusetts to propel the barge at a leisurely two to three knots. ${ }^{72}$ Warping tugs, moved by pulling on a line attached to a fixed object, would help maneuver the barge. These measured three-by-seven pontoons also sported two outboard motors and a large anchor and winch to push and pull (warp) the large barges into position on the LST and off the beaches. ${ }^{73}$

From 14-31 August, tests with the prototype lighter barge took place at the Advance Base Proving Ground in Davisville. These trials would determine the maximum possible size of the barge with attached propulsion units which could carry the load of an LST over water gap from a half to one mile in length. The Navy conducted additional tests at nearby Point Judith to experience the effect of long ocean swells on the barge. LST-27 and LCT-362 worked with the sixby-thirty barge and two two-by-seven pontoon tugs. A committee composed of representatives of the Staff Commander of the 6th Amphibious Force, the British Admiralty, BuDocks and Proving Ground personnel observed the tests. Among the findings, the barge could be moored to the bow of an LST and cargo practically

\footnotetext{
70 Godfrey E. Wildman-Lushington to Thomas A. Hussey, "Directive," 31 July 1943, DEFE 2/1044, NA-Kew.

71 Navy Department, Bases, Vol. 2, 102-4.

72 Document, "Notes on Development," SMA; Huie, Can Do!, 117; Symonds, Neptune, 200.

73 13th Naval Construction Regiment (NCR), "Construction Battalion Activity in the United Kingdom - A History," 8 November 1944, 41, SMA.
} 
unloaded onto the barge. The barge's configuration proved easily able to transport a 300 long ton load with a draft of three feet, two inches. Use of the barge to unload an LST also permitted the ships to forgo beaching, permitting tonnage load of vehicles to be approximately doubled when minimum landing draft was not required. On 29 August, ten 32-ton medium tanks and two 11-ton halftracks were loaded in under five minutes aboard the test barge and ferried to shore three-quarter miles distant in an equal amount of time. LST-27 managed to tow the barge at a maximum speed of 8.6 knots. ${ }^{74}$ After observing the tests, the committee accepted the barge design while recognizing the need for additional refinement in the United Kingdom. ${ }^{75}$

In short order the lumbering barge received its name. During the tests of the prototype barge, a naval aviator flying overhead spied the barge with its outboard motor haunches at one end and the narrow, ramp end on the opposite. Bemused, the aviator referred to the contraption as resembling a rhinoceros. The "rhino ferry" was thus christened. ${ }^{76}$

As the trials with the rhino ferry proceeded, senior Allied leaders meeting in Quebec worked out the required number of pontoons to construct the causeways and Rhino ferries for Neptune. Upon receiving reports on the progress of the Davisville test, Captain Hughes Hallett, RN, informed Admiral Oscar C. Badger, Assistant Chief of Naval Operations for Logistics, that the COSSAC staff at Quadrant agreed to the pontoon requirements for Overlord listed in Table 1. Material to construct

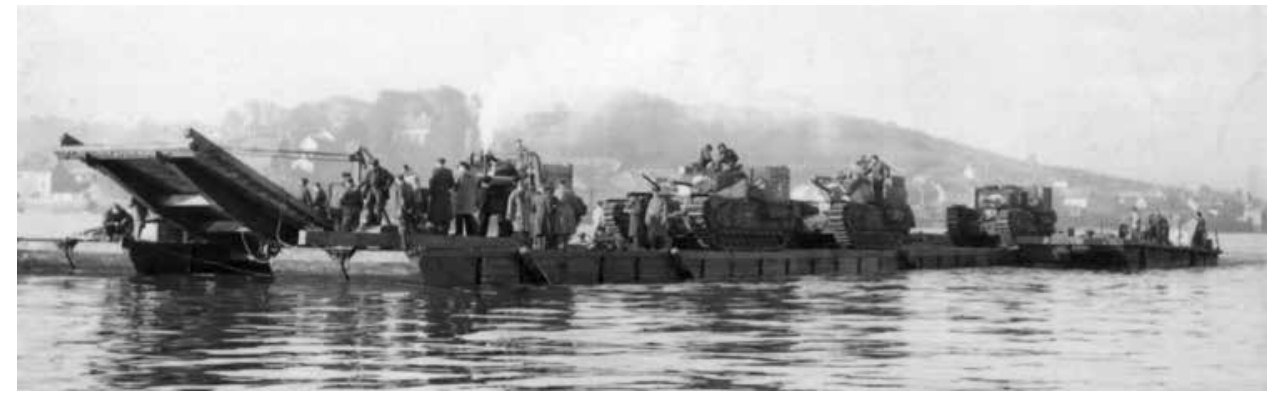

British rhino ferry in original configuration with rhino tug carrying a load of Churchill heavy tanks.

(Image provided by Andrew Hussey, Manston, UK)

74 William F. Royall to Ernest J. King, memorandum, subject: 6x30 N.L. Pontoon Barge for Unloading LST - Preliminary Report of Tests, 10 September 1943, DEFE 2/1010; document, X.R. 1476, "Trials of Rhino Barge Phoebe, Davisville Quebec, August 1943”; John N. Laycock to Ernest J. King, memorandum, subject: 6x30 NL Pontoon Rhino Barge for Unloading LST - Technical Report of Tests, 23 September 1943; R.W. Schepers to John N. Laycock, memorandum, subject: Surf Project, Technical Report of Trials of N.L. Pontoon Ferry Barge Conducted at the Advance Base Proving Ground, Davisville, R.I., 11 September 1943, DEFE 2/1063, NA-Kew.

75 Navy Department, Bases, Vol. 2, 103.

76 Laycock, "Rhino Ferries," SMA. The British initially referred to the barge as the "Phoebe" ferry. In a memorandum to Admiral King, Laycock referred to the barge as the "NL Pontoon 6x30 rhino barge.” John N. Laycock to Ernest J. King, memorandum, subject: 6x30 NL Pontoon Rhino Barge for Unloading LST - Technical Report of Tests, 23 September 1943, DEFE 2/1063, NA-Kew. 


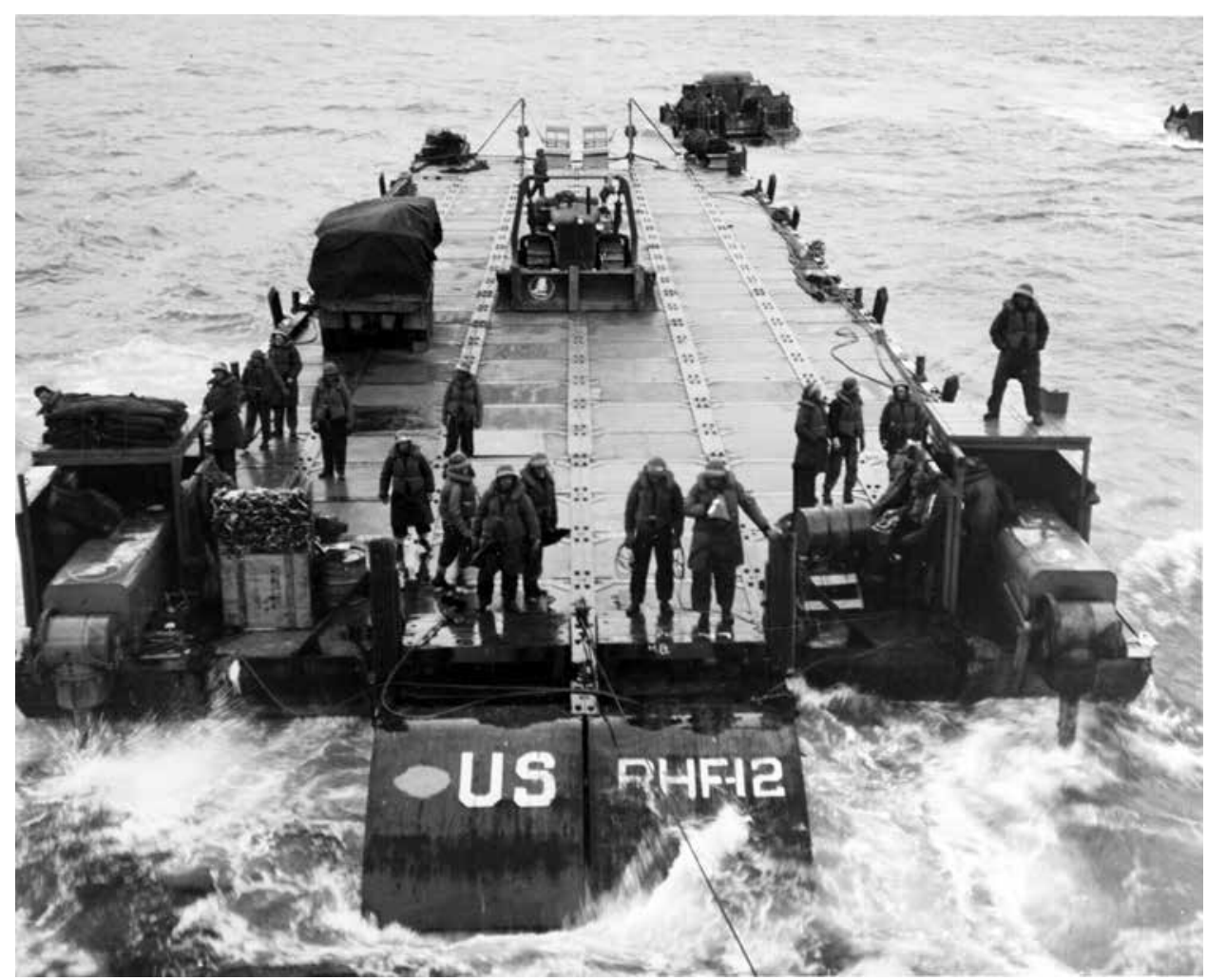

American rhino ferry RHF-12 off Omaha Beach, 6 June 1944 with design refinements visible at the bow and stern. (National Archives and Records Administration)

at least ten of the ferries needed to be in the United Kingdom no later than 1 November, with the remainder in place by 31 March $1944 .{ }^{77}$ By September the Admiralty refined the figures to further request 900 T6 and seventy T7 pontoons to provide ten percent spares for damaged ferry units. ${ }^{78}$ The required number of pontoon assemblies exceeded American supply, forcing the British to disassemble five pontoon drydocks and docks in the Mediterranean to ship the assemblies back to England for ferry and causeway construction. ${ }^{79}$

With the basic design for the rhino approved, efforts to refine the design shifted from Davisville, Rhode Island to several locations in England. At COXE

77 Cecil Charles Hughes-Hallett to Oscar C. Badger, memorandum, subject: British and US Requirements for N.L. Pontoon Equipment for 'Overlord', 22 August 1943, ADM 1/12851, NAKew.

78 Naval cypher from Admiralty to BAD Washington, 11 September 1943, ADM 1/12851, NAKew.

79 Naval cypher from BAD Washington to Admiralty and Commander in Chief Mediterranean, 6 September 1943; Naval cypher from Admiralty to Commander in Chief Mediterranean (Algiers), 11 September 1943; naval cypher from BAD Washington to Admiralty, 22 September 1943; naval cypher from Admiralty to BAD Washington, 7 October 1943; naval cypher from Commander in Chief Mediterranean to Admiralty, 30 October 1943, ADM 1/12851, NA-Kew. 


\begin{tabular}{|l|l|l|}
\hline NL Pontoon Craft & American (US Navy) & British (Royal Engineers) \\
\hline Rhino Ferries/Tugs & 28th, 81st, 111th NCB & $935,940,946,961,966$ IWT \\
\hline Causeways & CBD 1006 & 15 (Kent) GHQ Troops Engineers \\
\hline
\end{tabular}

Table 2. Units Assigned to naval landing pontoon craft for Overlord.

in Appledore, Devon, construction of a rhino ferry assumed highest priority with all available pontoon units being shipped to the facility to construct a smaller ferry for training purposes. ${ }^{80}$ In Falmouth, members of the 81st NCB stationed there received a shipment of pontoons from the United States on 15 November 1943. The Seabees, working under the direction of officers from the 13th Naval Construction Regiment (NCR), started assembling pontoon strings together to create a rhino tug and Rhino Ferry No. 1 (RHF-1), which launched on 7 December. CBD 1006, after manning causeways at Sicily and Salerno, arrived in England and set up headquarters in Exeter and later Plymouth. The men of CBD 1006, perhaps the most experienced pontoon outfit in the US Navy, worked in collaboration with the 81st NCB, 13th NCR, and Rear Admiral John Wilkes, Commander, Landing Craft and Bases, 11th Amphibious Force (COMLANCRAB11thPHIB), to test and refine the ferry into a craft suitable for the Overlord invasion. ${ }^{81}$

American tests and trial operations with the ferry in late December 1943 and early January 1944 found fault with several design aspects. With the approval of Wilkes, Seabees effected several changes. The visible changes included replacement of a sixty-ton ramp with lighter wood treadway ramps, which in turn necessitated the inversion of the two center T7 bow pontoons, and installation of plastic armor shelters around each outboard motor to protect the coxswains. ${ }^{82}$ The two center T7 stern pontoons were also inverted when paired with two vertical timber knee-braces on the ferry stern, spaced to engage the sides of the LST ramp when the ferry and ship mated..$^{83}$

Combined Operations also conducted trials at Appledore with a rhino ferry offloading LSTs and LCTs on flat beaches in February 1944. Via an agreement in October 1943, the Royal Navy would bring the Army to the seaward point of discharge, and the Army bore all responsibility for the "provision and operation of the means of crossing the "water gap," i.e. the rhino ferries and causeways. ${ }^{84}$

\footnotetext{
80 Chief of Combined Operations to Naval Officer in Charge Appledore, naval cypher, 8 October 1943, DEFE 2-1010; situation report from ADXOR, 23 September 1943, DEFE 2/1063, NA-Kew.

81 Samuel Eliot Morison, The Invasion of France and Germany, 1944-1945 (Boston: Little, Brown and Co., 1957), 63; Document, "Historical Resume of N.L. Pontoons in England and France;" 25th NCR, "Report of Activities of Twenty-Fifth US Naval Construction Regiment," 30 November 1944, 6; 13th NCR, "Construction Battalion Activity," 41; Naval Construction Battalion Detachment 1006 Historical Information packet, SMA.

82 Document, "Historical Resume of N.L. Pontoons in England and France;" 25th NCR, "Report of Activities," 6, SMA.

83 Navy Department, Bases, Vol. 2, 104.

84 N.L.B. Parker to War Cabinet, Principal Administrative Officers Committee, "Responsibility for Bridging the Water Gap,” 13 October 1943, DEFE 2/1133, NA-Kew.
} 
The British tests concluded the marrying of the rhino to an LST in fair weather conditions on the open sea "should present no particular difficulties," but recommended not using the two-by-seven tug units and instead modifying the propulsion system on the ferry itself. ${ }^{85}$ These tests used a rhino assembled by the British Army in Southampton which mirrored the original BuDocks design from August 1943. Having learned of the Seabees improvements to the ferry, the British Army agreed to adopt the American rhino ferry changes as standard for all ferries with only minor changes which further experience might find desirable. ${ }^{86}$

With the ferry design finalized for the operation, construction of a fleet of ferries commenced in earnest. As conditions at the assembly yard at Falmouth limited the launching of single one-by-thirty pontoon strings, two other assembly yards opened in Plymouth and Falmouth to produce enough pontoon strings to keep with the Overlord timetable. In January, the 13th NCR under the cognizance of Wilkes began to administer the entire rhino ferry program, assembly, and training. Crews for the ferries, tugs, and pontoon causeways consisted of the US Navy's Seabees for the forces at Omaha and Utah, and British Army sappers and pioneers from Inland Water Transport Companies (IWT), Royal Engineers for the rhinos and causeways with the forces at Gold, Juno, and Sword. ${ }^{87}$

Training for rhino crews by the Seabees and Royal Engineers varied. The Americans chose shore locations resembling the conditions at Omaha and Utah beaches. Seabees manhandled the rhinos at Fowey, Falmouth, Dartmouth, Torquay, and Plymouth while others beached and repositioned causeways at Par Sands and Fowey. The Navy provided LSTs and the Army's 29th Infantry Division loaned vehicles for training. Due to the priority placed on pontoon assembly, however, most American crews received only two to three days of training on the ferries on the relatively quiet waters at Dartmouth. ${ }^{88}$

After extensive trials with the ferries, COXE recommended that the rhinos be manned by fully trained crews with at least a month's experience handling the ferry in operational conditions. Near the Isle of Wight in relatively calm conditions, British rhino crews received more time with the craft than the Americans, and British leadership sought to arrange training for the rhino crews in various exercises for the British and Canadian assault forces. But ideal sea conditions could give

\footnotetext{
85 Commandant, COXE, Interim Report on Trials at Combined Operations Experimental Establishment (COXE) TN Wing, "Rhino Ferry," 21 February 1944, DEFE 2/1063, NA-Kew.

86 Minutes of Special Meeting in Connection with Arrangements for the Assembly of Rhino Ferries, Etc Held in Room 412, Rotunda at 1500 hours on 29 February 1944, DEFE 2/1063, NA-Kew.

87 David Habesch, The Army's Navy: British Military Vessels and Their History Since Henry VIII (London: Chatham Pub., 2001), 98-100. The Inland Water Transport Companies have nary a mention in the published orders for Neptune. The identities of these companies were determined via secondary order of battle listings available online.

88 Officer in Charge, 13th US NCR, memorandum, subject: Mulberry Training - Progress of, 26 March 1944; 13th NCR, "Construction Battalion Activity," 41-42; Director (B-1), Advance Base Department, BuDocks, memorandum, subject: Report on use of N.L. Pontoon Equipment by Amphibious Forces on Normandy Beach, undated; 25th NCR, "Report of Activities," 9-10, SMA.
} 
a false sense of security. Four rhinos participated in exercise Gold Braid where good weather conditions made easy work of unloading from LSTs and Liberty ships. By April, rhino ferry crew sizes were determined to be twenty-six men for the American ferries (one officer, twenty-five enlisted) and twenty-one men for the British (one officer, twenty enlisted), with 100 percent spare crews to enable twenty-four hour operations. ${ }^{89}$

As work progressed on the ferries and tugs, engineers at Supreme Headquarters Allied Expeditionary Force (SHAEF) recommended installation of pontoon causeways on the invasion beaches. These would provide another means to bridge the ship-to-shore offloading requirements until the Mulberries were operational, able to handle half of the daily total of ferry cargo discharged. Leveraging the twoby-thirty pontoon structure or "string" as the base element, the causeways would be assembled and sunk in place to extend from the high-water line to just beyond the line of minimum low water. A total of fourteen strings would be connected end to end, producing a 2,450-foot-long pontoon roadway. Each of the American invasion beaches would have two of these causeways installed. ${ }^{90}$ For the British and Canadian beaches, there would be two causeways each for Gold and Juno, with one allotted to Sword. ${ }^{91}$ While the rhinos would concentrate on unloading LSTs and Liberty ships converted for maximum vehicle-carrying purposes anchored offshore (referred to as MTs), the causeways would serve smaller vessels, predominantly the LCT. These craft could handle four to five tanks or heavy trucks in an open cargo bay and featured large bow doors and a ramp for the vehicles to drive out from the cargo bay onto the beach. ${ }^{92}$

In February 1944, a causeway program began with a series of experiments along the southern coast of England.${ }^{93}$ Given highest priority with rhino trials, COXE sought to determine the practicability of using sunken long causeways to solve LCT water gap. ${ }^{94}$ At Swan Pool Cove, Falmouth on 3 February, men from CBD 1006, the commanding officer of US Naval Advanced Amphibious Base, Falmouth, and members of the 15 (Kent) GHQ Troops Engineers moved a pair of causeway units via pontoon tug to the beach. Once in place, it took twenty to thirty minutes to flood the units completely. The pontoons rested neatly on the bottom; at low tide the men drained the pontoons, then floated the causeway out at high tide. Additional tests over the coming days experimented with a floating fourby-twenty-four pontoon pierhead with LCTs using the pierhead and a specialized

\footnotetext{
89 Minutes of the Second Meeting held at 15.00 hours in Room 476, Metropole Buildings, Northumberland Avenue, W.C.2., 3 April 1944, DEFE 2/1063, NA-Kew.

$90 \quad$ Navy Department, Bases, Vol. 2, 103-4.

9115 (Kent) GHQ Troops Engineers, "Technical and Other Notes on N-L Pontoon Causeways, June-July 1944,” 29 July 1944, WO 205/1193, NA-Kew.

92 Symonds, Neptune, 150-52.

93 The initial proposal for a 3,000-foot-long causeway for disembarking LCTs dates to 22 January. Chief of Combined Operations to NOIC Appledore for Commandant COXE, 22 January 1944, DEFE 2/1130, NA-Kew.

94 COXE, Experimental Project Sheet, Project No. 152, 30 January 1944, DEFE 2/1130, NA-Kew.
} 


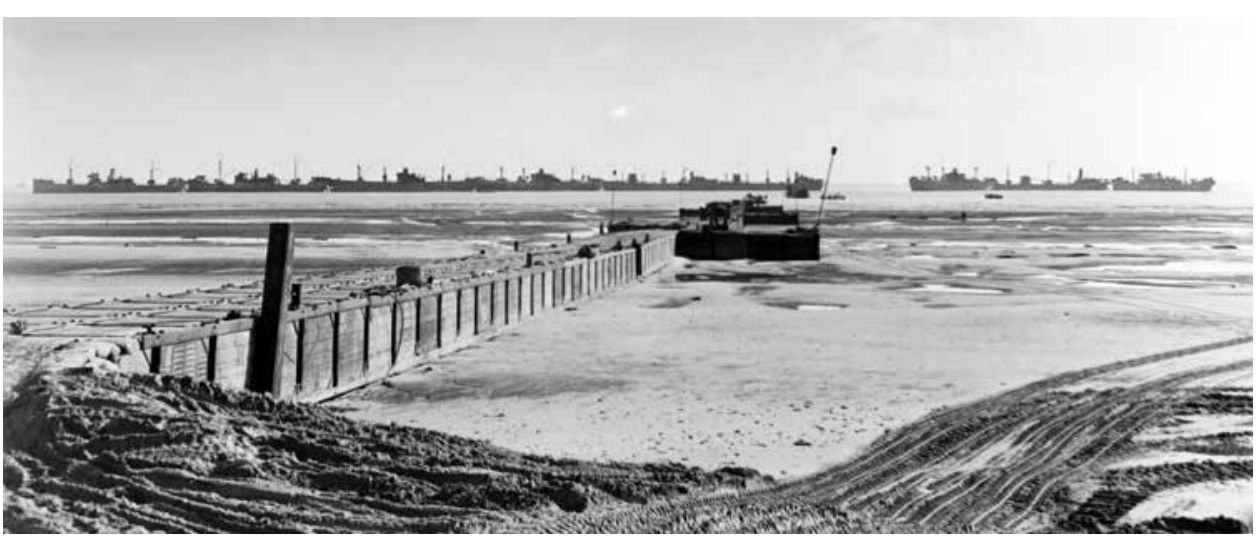

Causeway No. 2 at Omaha Beach at low tide with blisters visible, 12 June 1944. Part of the gooseberry breakwater of Mulberry A can be seen in the background. (National Archives and Records Administration)

timber landing mat to move vehicles onto the sunken causeway and then ashore. From the experiments the senior engineers concluded that the flooded pontoon causeway provided a stable roadway and worked best on a relatively flat beach. A long causeway, rather than a short one, proved ideal on account of reduced pitching motion. ${ }^{95}$ Further experiments on flatter beaches in Cornwall demonstrated challenges with sinking and anchoring the causeway, but more so with the floating pierhead, causing one officer to conclude "the causeway is going to contribute very little" to the flow of required vehicles ashore. ${ }^{96}$

The men of CBD 1006 and the Royal Engineers continued work with the sunken causeways at their proving grounds at Fowey. Continued experimentation in March and April concluded the sunken causeways worked best without a floating pierhead. Engineers decided instead to mount four-by-twelve pontoon blisters to the causeway, spaced intermittently from 250-350 feet apart along both sides of the causeway. This arrangement ensured one blister would always be available for unloading LCTs regardless of the tidal conditions in waters from four to six and half feet deep. Unwaterproofed vehicles could be discharged twenty-four hours a day and soldiers walk ashore in the dry as opposed to wading in the surf. ${ }^{97}$ At

95 John Wilkes, Commander, Landing Craft and Bases, Eleventh Amphibious Force, to Commander, Task Force 122, memorandum, subject: Sunken Causeways, Experiments with, 21 March 1944, SMA; Report on Trials of Long Sunken N.L. Causeway at Falmouth, 5 February 1944, DEFE 2/1130, NA-Kew.

96 J.S. Mulock to Naval Officer in Charge, Appledoor, memorandum, 14 March 1944, SMA.

97 13th NCR, "Construction Battalion Activity," 42-43; 25th NCR, "Report of Activities," 6-7; Wesley C. Pietz to Douglas C. Jardine, memorandum, subject: Sunken N.L. Pontoon Causeways - Use of Float with, 21 April 1944; Office of the Allied Naval Commander, Expeditionary Force, "N.L. Pontoon Causeways," 13 May 1944, SMA; Navy Department, Bases, Vol. 2, 104; Extract from Report by A.D.A.Tn. C.O.H.Q. on Trials of Sunken N.L. Pier with Floating Pierhead - Falmouth 5.2.44., 23 February 1944; Office of Allied Naval Commander, Expeditionary Force, N.L. Pontoon Causeways, 13 May 1944, DEFE 2/1130, NA-Kew. The British causeways used blisters measuring $4 \times 10$ units. 
Southampton, 15 (Kent) GHQ Troops Engineers prepared the causeway equipment for the Eastern Task Force, assembling eighty-one two-by-thirty sections, fortyeight four-by-ten blisters, twenty-two three-by-seven tugs, and four warping tugs. ${ }^{98}$

As the Seabee role increased the Navy opted to reorganize the forces directly involved with Overlord. On 1 April, BuDocks established the 25th NCR for the purpose of training, organizing, and planning invasion operations. The regiment would supervise all Seabee activities on the "Far Shore" of France, including, among others, construction of Mulberry A off Omaha, rehabilitation of captured ports, and the operation of all pontoon ferries, tugs, and causeways. By 15 April, the 13th NCR finished overseeing construction of twenty-seven rhino ferries and the 25th NCR took command of all pontoon assembly yards. SHAEF planners soon issued orders for construction of fifty-six two-by-thirty causeway sections, thirty-two four-by-twelve blisters, twelve two-by-seven pontoon causeway tugs, and twelve warping tugs for the Western Task Force assigned to land on Omaha and Utah. ${ }^{99}$

As D-Day crept closer, SHAEF also decided to increase the ferry force. Of the fifty-five Rhinos originally ordered by SHAEF, twenty-seven were allocated to the Americans and twenty-eight to the British. ${ }^{100}$ In early March, SHAEF determined the initial fifty-five rhino allocation offered no reserve or flexibility and would be insufficient in terms of wastage, and thereafter requested construction of twenty additional ferries equally divided between the American and British forces. ${ }^{101}$ For the invasion, the British received thirty-nine rhinos, with thirty-one assigned to the Americans with five ferries kept in reserve. ${ }^{102}$

For the Western Task Force landings, the US Navy Task Force 127 and the 25th NCR organized the pontoon barges and causeways to arrive between D-Day to 9 June. The first tide would deliver eight rhinos to Omaha and four to Utah, with the second tide bringing eleven and eight rhinos to each beach, respectively. Seabees of the 111th NCB manned the Omaha force rhinos; Seabees of the 81st NCB manned

9815 (Kent), "Technical and Other Notes," WO 205/1193, NA-Kew.

99 Navy Department, Bases, Vol. 2, 109; 13th NCR, "Construction Battalion Activity," 17-18; document, "Historical Resume of N.L. Pontoons in England and France;" 25th NCR, "Report of Activities," 1-7, SMA.

100 J.W. Rivett-Carnac to Commander-in-Chef, 21 Army Group, memorandum, subject: Rhino Ferries, 21 December 1943, DEFE 2/1063, NA-Kew.

101 Message from G-4, SHAEF to COMNAVEU, 13 March 1944; message from COMNAVEU to CNO, 16 March 1944, WO 219/906, NA-Kew.

102 Commander, US Naval Forces in Europe to Commander in Chief, United States Fleet, and Chief of Naval Operations, and Supreme Commander Allied Expeditionary Force, memorandum, subject: Operation Report of Naval Commander Western Task Force (CTF 122), 25 July 1944, Defense Technical Information Center, Fort Belvoir, VA. The five reserve rhinos were later assigned to the American Western Task Force after the Channel storm of 19-22 June 1944. Naval Commander, Western Task Force (CFT 122) to Commander-in-Chief, United States Fleet and Chief of Naval Operations, memorandum, subject: Operation Overlord - Report of Naval Commander, Western Task Force (C.T.F. 122), 25 July 1944, Annex C - Logistics, Reel A1795, p. 523, WWII-WD, RG38, NARA. 


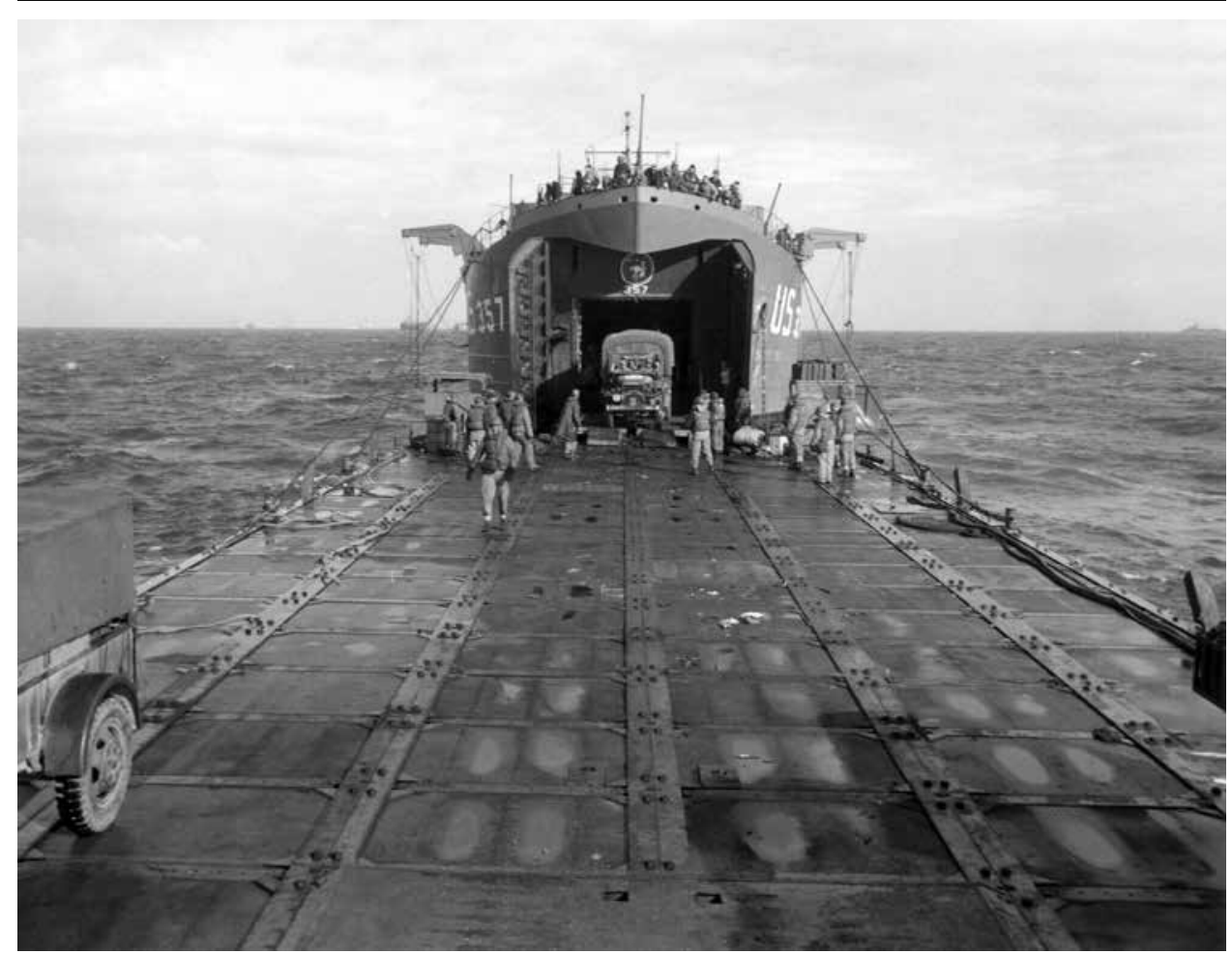

USS LST-357 married up to a rhino ferry off Omaha Beach, June 1944. (US Navy Seabee Museum)

USS LST-21 offloading British armor and vehicles onto a rhino ferry, possibly RHF-100, off Gold Beach, 6 June 1944. (National Archives and Records Administration)

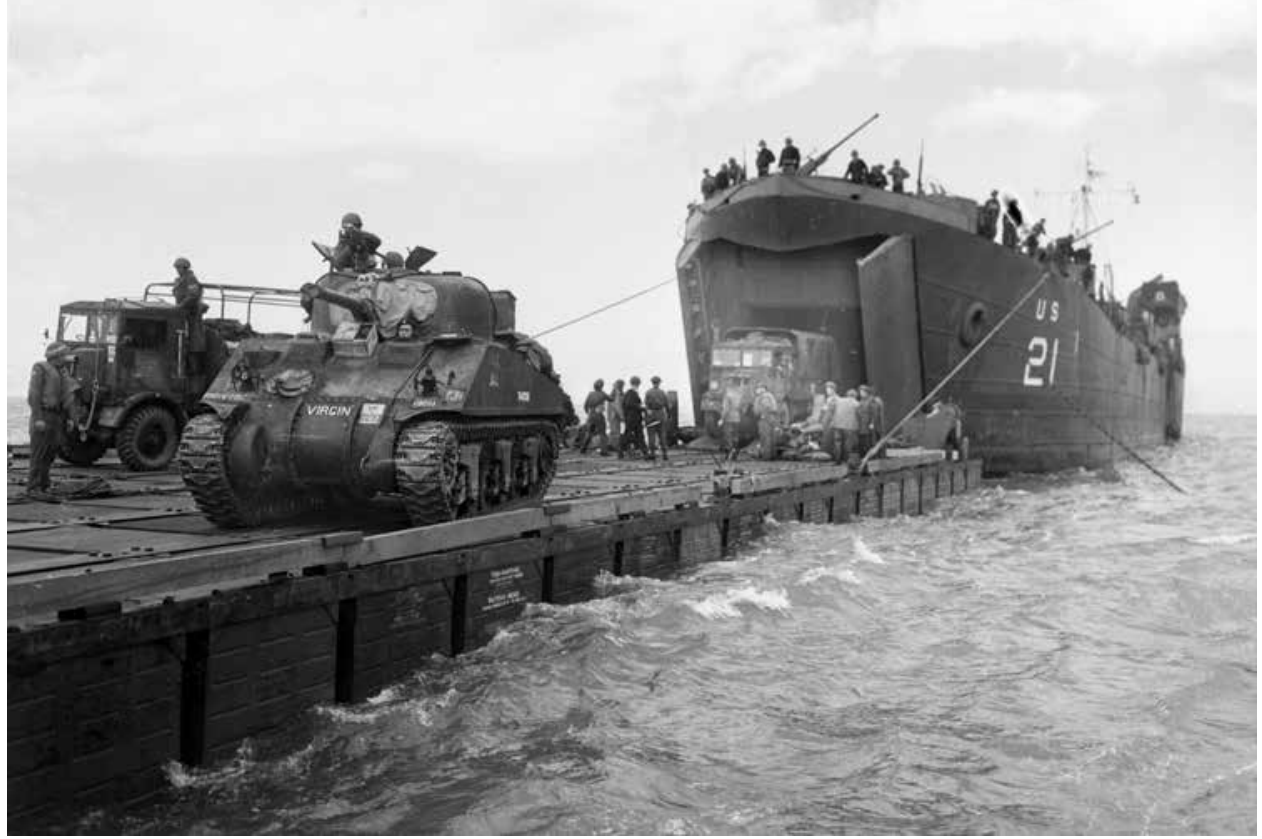


the Utah rhinos. Seabees of the CBD 1006 would man the causeways, blisters, and tugs for both beaches. The causeway sections, blisters, tugs, and warping tugs would begin to arrive on 7 June with installation commencing on the causeways no later than 9 June. ${ }^{103}$

For the Eastern Task Force assigned to land on Gold, Juno, and Sword, LSTs towing the rhino ferries would all arrive on D-Day at the first and second tides. Gold Beach had fifteen allotted rhinos manned by 935 IWT; fifteen rhinos, manned by 966 IWT, would head to Juno Beach; Sword Beach received the remaining nine rhinos, manned by 940 IWT. ${ }^{104}$ The 15 (Kent) GHQ Troops Engineers, who would build and maintain causeways at Gold, Juno, and Sword Beaches, would have all shore parties arrive between D-Day and 8 June. From 7 to 9 June, causeways sections and blisters would arrive at Juno and Gold Beaches for assembly and installation. ${ }^{105}$

The problem of building up an adequate level of supplies weighed heavily on Neptune's planners. The rhinos and causeways collectively would play a critical role in solving that problem. Neptune's naval orders noted "[t]he speed with which subsequent formations and stores are landed is equal in importance to the initial assaults. In order that the latter may be sustained and that our rate of reinforcement may match that of the enemy, a great volume of shipping and craft must be discharged without delay continuously throughout the first few weeks of the operation." ${ }^{106}$ Rhinos would begin the process of unloading LSTs on D-Day, and causeways would start to take form on 7 June.

\section{Normandy}

By the morning hours of 5 June, the vast armada was on the move. With fourfoot seas on pontoon ferries enjoying only two feet of freeboard, the Seabees aboard the craft endured miserable conditions. Some Seabees opened individual pontoons to find some shelter inside while others made fires on the ferry decks to

\footnotetext{
103 Navy Department, Bases, Vol. 2., 110-11; 25th NCR, "Report of Activities," 11-16; Commander, Task Force 127 to Naval Commander, Eastern Task Force, memorandum, subject: N.L. Pontoon Equipment for Overlord, undated (May 1944?), SMA; Operation Neptune - Naval Orders, ON 7 - Instructions to Task Force and Assault Forces Prior to H Hour, Reel A1805, p. 108, WWII-WD, RG38, NARA.

104 Senior Officer Ferry Control Gold Area, to Naval Officer-in-Charge, Gold Area, memorandum, 9 July 1944, DEFE 2-416; Naval Commander Force "J" to the Naval Commander, Eastern Task Force, memorandum, subject: Report on Operation "Neptune," 4 July 1944, DEFE 2/418, NA-Kew; Operation Neptune - Naval Orders, ON 7 - Instructions to Task Force and Assault Forces Prior to H Hour, Reel A1805, p. 108; Operation "Neptune" - Eastern Task Force Naval Plan, 10, Reel A1805, p. 3455, WWII-WD, RG38, NARA. Fifteen rhinos were planned for Gold Beach, but only 14 left England for the far shore.

10515 (Kent) GHQ Troops Engineers, Operation Order No. 1, Overlord - Neptune, 25 May 1944, DEFE 2/423, NA-Kew; Operation Neptune - Naval Orders, ON 10 - Instructions for Follow-up Forces, Reel A1803, p. 153, WWII-WD, RG38, NARA.

106 Operation Neptune - Naval Orders, ON 13 - Instructions for the Build Up, Reel A1803, p. 185, WWII-WD, RG38, NARA.
} 
heat rations or used acetylene torches to make coffee. ${ }^{107}$ The towing of the ferries and tugs occurred without serious incidents, although some of the craft broke free due to insufficient one and a half-inch wire rope for tow lines. ${ }^{108}$ At 0530 on D-Day, the rhino ferries and tugs arrived off Omaha and cast off the lines to commence marrying up with the LSTs. Heavy seas with six-foot wave crests complicated the "marriage arrangements" and some ferries lost their timber knee braces. Once

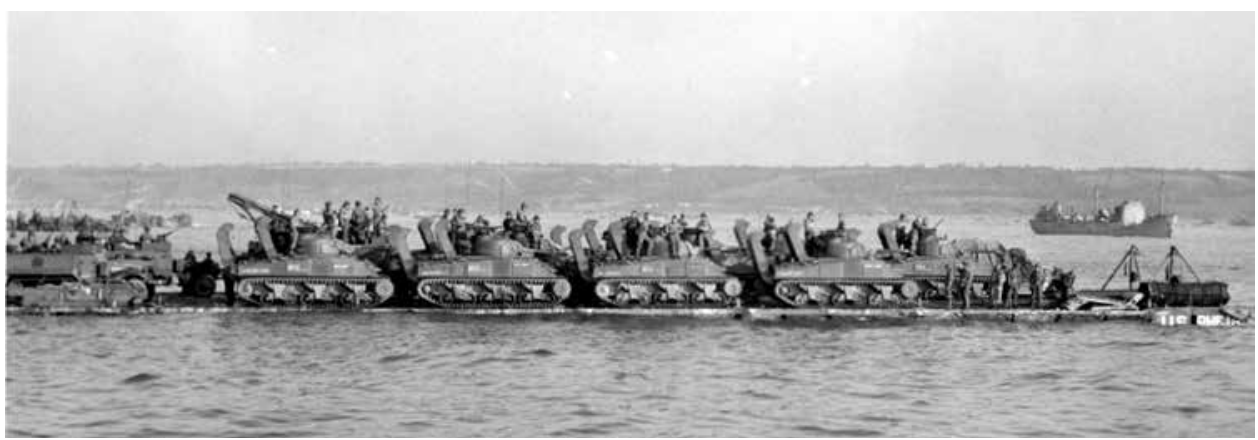

Rhino ferry RHF-18 carrying a load of armored vehicles to Omaha Beach with a freeboard of inches in places. (US Navy Seabee Museum, Port Hueneme, CA)

loaded, the five ferries moved to the beach twelve miles distant between 0700 and 0800. Force U's rhinos arrived off Utah at 0300 . Rough seas resulted in only four of the five rhinos mating with the LSTs, which then headed to the beach ten miles distant. ${ }^{109}$

Combat conditions on the invasion beaches varied considerably and affected initial rhino landings. At Omaha, the ferries received orders to stand off until beach obstacles were cleared, a tall order considering the horrible losses suffered by the Gap Assault Teams composed of trained Army Combat Engineers and Navy Combat Demolition Units tasked to destroy beach obstacles at low tide and open gaps in the defense before infantry and armor came ashore. ${ }^{110}$ Unaware of the order to stand by, RHF-10 chugged to the beachhead despite the risks and reached the shore at noon, managing to beach itself in a gap between the obstacles, although the ferry remained in place for the remainder of the day until mines astern of the rhino were removed. ${ }^{111}$ Lieutenant Floyd Richards of LST-133 at Omaha lauded

\footnotetext{
107 Symonds, Neptune, 245-46; Huie, Okinawa, 180.

108 Director, Advance Base Department, BuDocks, memorandum, subject: Report on use of N.L. Pontoon Equipment by Amphibious Forces on Normandy Beach, undated, SMA; Pyle, "Too Sleepy," 1.

109 Navy Department, Bases, Vol. 2, 111; 25th NCR, "Report of Activities," 12, 15, SMA.

110 Symonds, Neptune, 272-75; Francis D. Fane and Don Moore, The Naked Warriors: The Story of US Navy's Frogmen (Annapolis, MD: Naval Institute Press, 1995), 49-73.

111 Navy Department, Bases, Vol. 2, 111-12; 25th NCR, "Report of Activities," 12; Executive Officer, 25th USN Construction Regiment to Officer in Charge, 25th USN Construction Regiment, memorandum, subject: Action Report - Seabee Activities on Far Shore, 23 June 1944, SMA.
} 


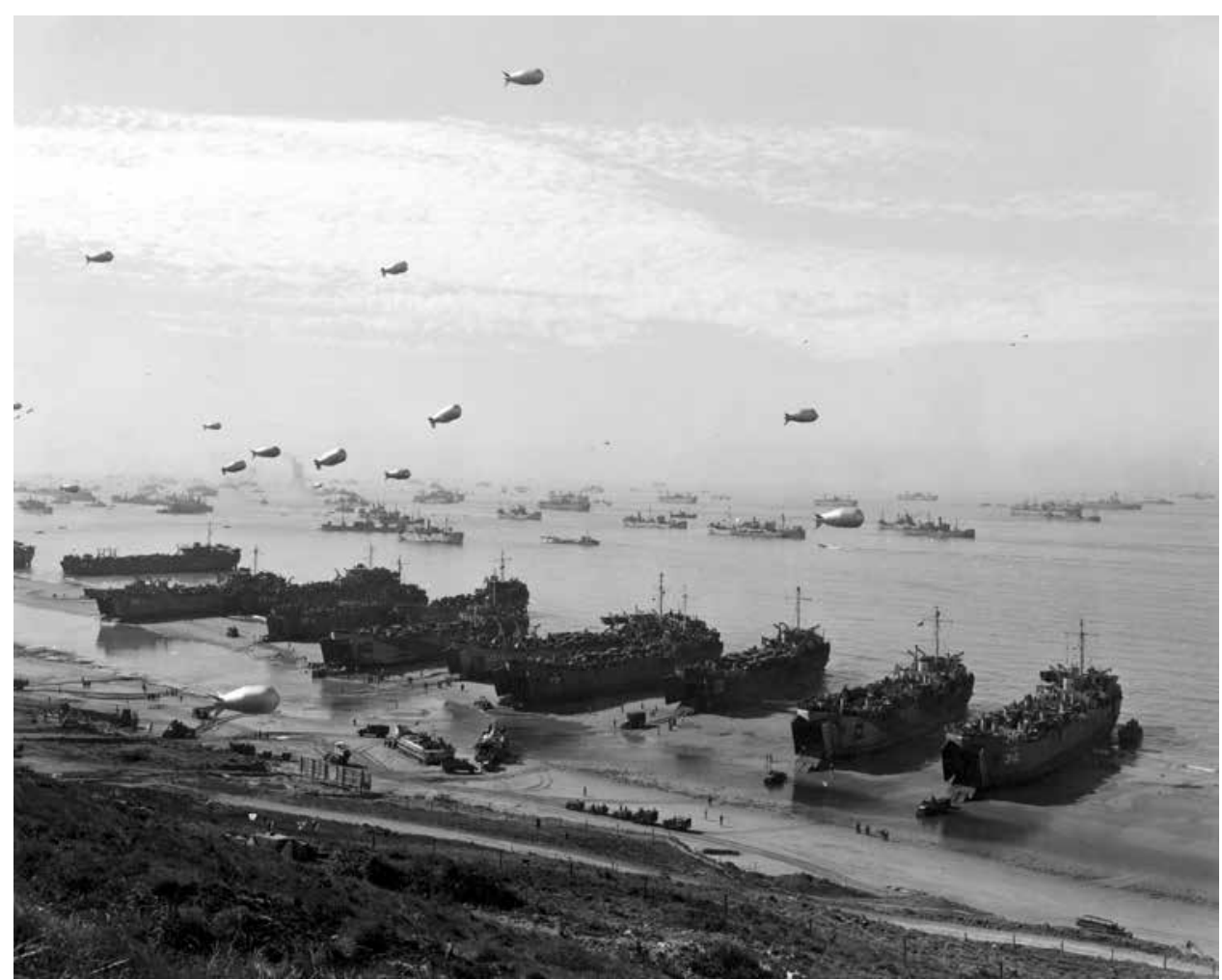

British and American LSTs offloading directly on Omaha Beach, on or after 10 June 1944. (National Archives and Records Administration)

the Seabee rhino crews, recalling how one he encountered had been operating for eighteen straight hours, failed to land due to enemy artillery fire, and yet "their spirits were still high and when it was possible to return to the beaches ... they set off on their task calmly and without hesitation." 112 At Utah, the assault forces fortuitously landed half a mile south of their objectives in an area of weaker German defenses. ${ }^{113}$ The first of the four rhinos, RHF-21, landed at 1400 hours followed by the other three; by midnight all had unloaded a combined total of 175 vehicles. ${ }^{114}$

The British experience with the Rhinos proved less than satisfactory. The crosschannel tows resulted in the loss of one rhino ferry each from the assault forces assigned to Sword, Juno, and Gold, while seventeen out of thirty rhino tugs broke free and were lost. Once off the Normandy coast, the rough seas made marrying of ferry and LST a difficult proposition which placed the discharge of supplies

112 Greg H. Williams, The US Navy at Normandy: Fleet Organization and Operations in the D-Day Invasion (Jefferson, NC: McFarland and Co., Inc., Pubs, 2020), 307.

113 Symonds, Neptune, 271-72; Rick Atkinson, The Guns at Last Light: The War in Western Europe, 1944-1945 (New York: Henry Holt and Co., 2013), 61-64; Morison, France and Germany, 97-102.

114 Memorandum, subject: Action Report - Seabee Activities on Far Shore, SMA; Navy Department, Bases, Vol. 2, 112. 
badly behind schedule. ${ }^{115}$ The rhinos at Gold began unloading LSTs around noon on D-Day but a lack of any beach organization to unload the ferries caused difficulties. Around 0200 on 7 June, Captain George Verner Motley Dolphin, RN, Gold Beach Naval-Officer-in-Charge, came across two ferries broaching in the surf with no assistance from shore. He personally took command of a tractor to haul the ferries square to the beach and with assistance of two army officers he unloaded the ferries. ${ }^{116}$ At Juno, engineers were unable to clear many submerged beach obstacles until the afternoon of D-Day. The first loaded Rhinos headed to

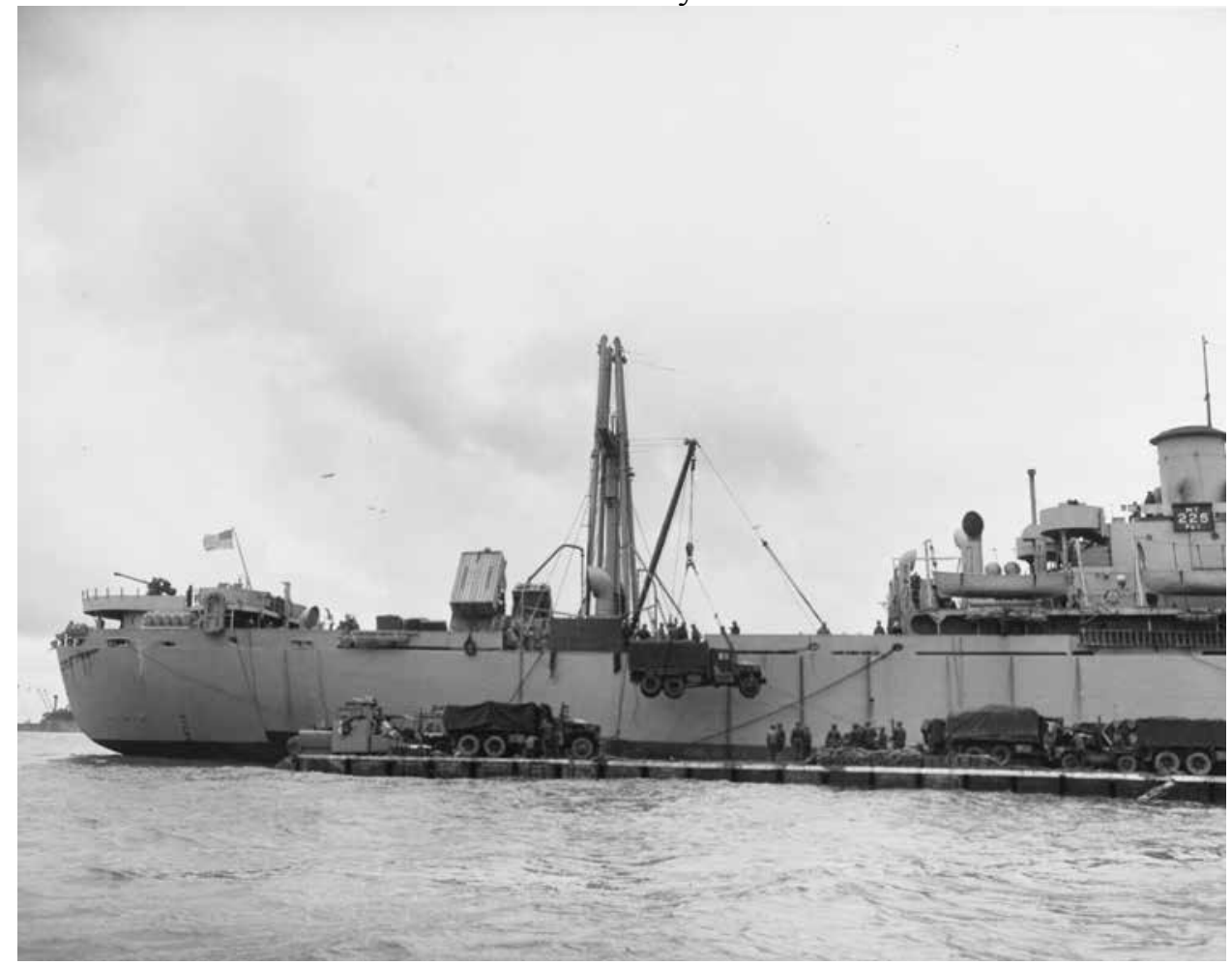

A Liberty ship, marked MT 225, offloading vehicles onto a rhino ferry, 10 June 1944. (National Archives and Records Administration)

the shore at 1500 and 1545 hours but several struck Teller mines on submerged obstacles and were put out of action. Prior to midnight, weather conditions halted further operations, with eight ferries left stranded on the beach. ${ }^{117}$ Sword missed the rhino tugs lost during the cross-channel tow in the initial unloading of LSTs,

115 Naval Commander Eastern Task Force to Allied Naval Commander Expeditionary Force, memorandum, subject: Operation Neptune - Report of Naval Commander Eastern Task Force, 21 August 1944, DEFE 2/414, NA-Kew.

116 Naval Officer-in-Charge, Gold Beach, to Naval Commander, Force "G," 22 June 1944, DEFE 2/416, NA-Kew.

117 Memorandum, subject: Report on Operation "Neptune," DEFE 2/418, NA-Kew. 
but otherwise experienced no major issues. ${ }^{118}$

On 7 June with the beaches secure, the American rhino force expanded operations. Six additional rhinos arrived at Utah in the early hours and all eleven operated throughout the day despite enemy artillery fire and air attack. One attack by enemy aircraft destroyed one rhino tug and inflicted a dozen Seabee casualties. The fifteen additional rhinos arrived at Omaha and those held offshore on 6 June landed at 1130 and discharged cargoes of varying mass. One rhino from LST350 came ashore at Omaha with a load of twelve M4A1 Sherman medium tanks which left the ferry with a freeboard at places of mere inches. ${ }^{119}$ Two ferries struck mines, resulting in the destruction of one complete pontoon and the puncturing of adjacent units. One rhino tug struck a mine which blew its inboard engine on deck, knocking the vessel out of action. The rhino repair barges arrived off Utah and Omaha the same day, the latter effecting immediate repairs to the damaged craft, helping quickly place the ferries back in operation. The repair barge crew off Omaha worked seventeen-hour days, repairing not only pontoons but practically every watercraft in need. Enemy fire began to range on the rhinos at Omaha inflicting several causalities to the Seabees. Undeterred, the rhino crews proved invaluable on the seventh by landing an urgently needed load of artillery pieces for the infantry divisions ashore. ${ }^{120}$

The rhino forces almost immediately commenced 24-hour operations to meet the pressing supply demand. By 7 June in the British Assault Area, approximately 100 LSTs waited to be unloaded and only half the rhino force remained barely

\begin{tabular}{|l|l|l|r|}
\hline Beach & Causeway & Construction Completed & Length \\
\hline Utah & Easterly No. 1 & 9 June & 2,200 feet \\
\hline Utah & Westerly No. 2 & 15 June & 2,200 feet \\
\hline Omaha & Easterly No. 1 & 11 June & 1,456 feet \\
\hline Omaha & Westerly No. 2 & 16 June & 1,050 feet \\
\hline
\end{tabular}

Table 3. American causeways constructed at Utah and Omaha Beaches.

operational. The number of operational rhinos had declined due to increasing damage to the propulsion units while beaching. ${ }^{121}$ Omaha remained in shambles

\footnotetext{
118 Naval Commander Force "S" to Naval Commander, Eastern Task Force, memorandum, subject: Report by the Naval Commander, Force "S," 22 July 1944, Reel A1795, p. 239, WWII-WD, RG38, NARA.

119 The M4A1 Sherman medium tank weighed approximately 33.4 tons combat loaded. R.P. Hunnicutt, Sherman: A History of the American Medium Tank (Novato, CA: Presidio Press, 1978), 540.

120 Memorandum, subject: Action Report - Seabee Activities on Far Shore; 25th NCR, "Report of Activities," 12, 15-16, SMA; J.F. Conroy, commanding officer, LST-350, to Naval Commander Western Task Force, memorandum, subject: Chronological Narrative Report of Invasion, Submitting of, 13 July 1944, Report of Operations in the Invasion of Normandy, France, 6/2-17/44, Reel A1160, WWII-WD, RG38, NARA.

${ }_{121}$ Memorandum, subject: Operation Neptune, DEFE 2/414, NA-Kew. Captain Dolphin at Gold Beach, after unloading two rhino ferries, reported "Influenced by this baleful sight I took the decision
} 


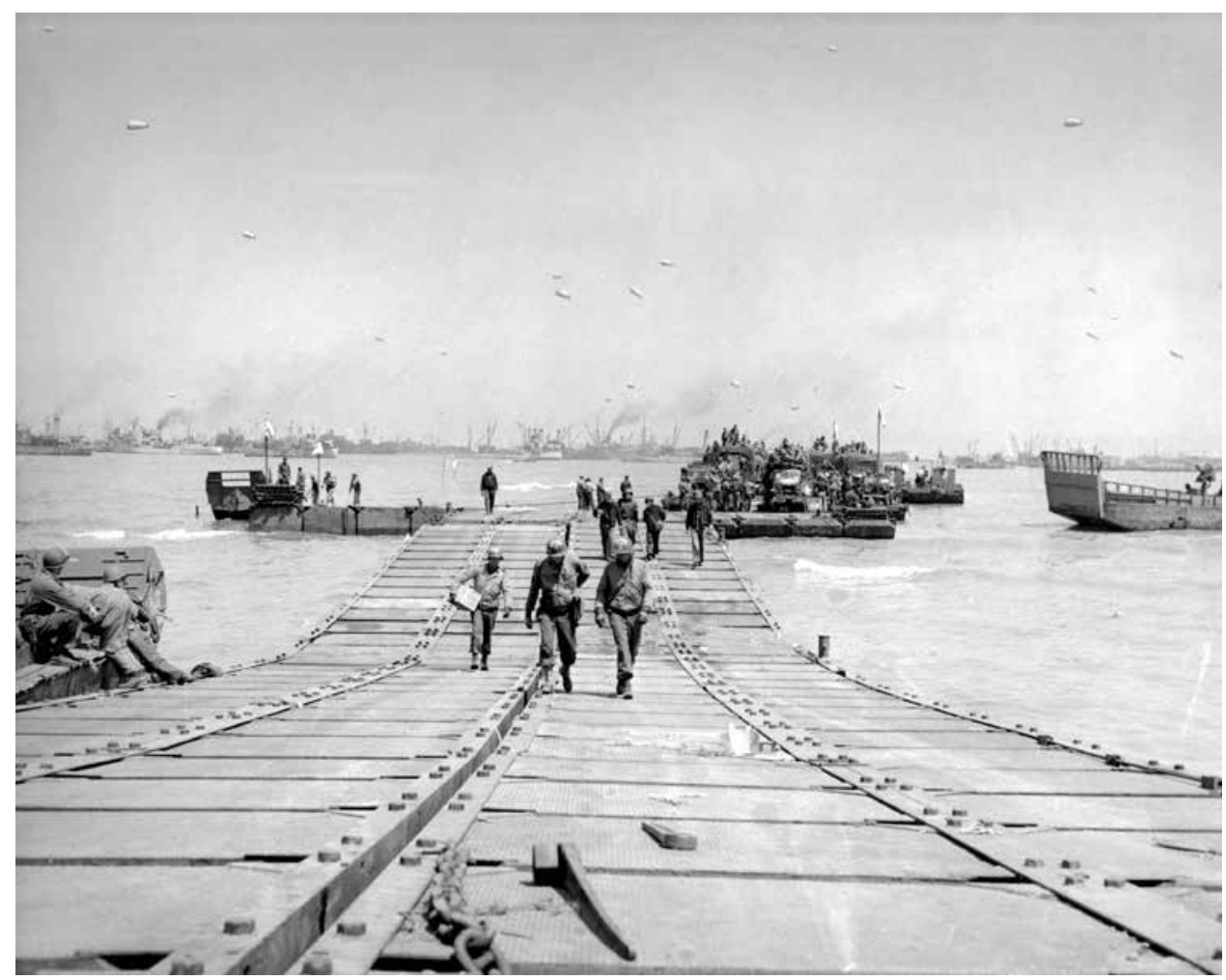

Civil Engineer Corps officers from the 111th Naval Construction Battalion walking across a doublewide causeway at Omaha Beach. (National Archives and Records Administration)

after the initial landings, with a total of only 4,581 tons of supplies landed by 9 June, rather than the planned 8,000 tons daily. To address the growing offloading delays on account of the failure of the British rhino force, Admiral Sir Bertram Ramsay, Naval Commander-in-Chief of the Allied Expeditionary Force, authorized the beaching of LSTs at the British, Canadian, and Utah invasion beaches. At Omaha with enemy artillery still a threat, the rhino ferries and smaller craft carried the bulk of material ashore until 10 June, when Ramsay authorized LSTs to beach themselves to offload. ${ }^{122}$ Rhinos thus provided the only means to land large numbers of vehicles at Omaha. ${ }^{123}$ Following Ramsay's order, the American and British rhinos switched from unloading LSTs to serving as lighters for MT ships. ${ }^{124}$

the following day that LSTs were to beach. This became my firm policy." Naval Officer-in-Charge, Gold Beach, to Naval Commander, Force "G," 22 June 1944, DEFE 2/416, NA-Kew.

${ }_{122}$ Symonds, Neptune, 308-14.

${ }^{123}$ Provisional Engineer Special Brigade Group, "Operation Neptune Report: Omaha Beach, 26 February - 26 June 1944," 30 September 1944, 157-58, File No. 493F, Operation Neptune Monograph, Prov. Engr Special Brigade Gr., Administrative History Collection, Historical Section, ETOUSA, Reel MP63-9_0081, Records of Headquarters, European Theater of Operations, United States Army, Record Group 498 (RG498), NARA.

${ }_{124}$ Ruppenthal, Logistical, 587; memorandum, subject: Operation Neptune, DEFE 2/414; Operation Neptune Part IVA, Report of Naval Commander, Eastern Task Force, Parts I-VI, 1944; Naval Officer- 


\begin{tabular}{|l|l|l|r|}
\hline Beach & Causeway No. & Construction Completed & Length \\
\hline Gold & 1 & 22 June & 1,407 feet \\
\hline Gold & 2 & 16 June & 1,233 feet \\
\hline Gold & 3 & 5 July & 2,817 feet \\
\hline Sword & 4 & -- & 704 feet \\
\hline Juno & 5 & 8 July & 2,289 feet \\
\hline Juno & 6 & 11 July & 2,640 feet \\
\hline Juno & 7 & 28 July & 2,082 feet \\
\hline
\end{tabular}

Table 4. British causeways constructed at Gold, Juno, and Sword Beaches.

By 12 June, a total of 8,529 tons of cargo landed at Omaha, finally surpassing the planned daily tonnage. ${ }^{125}$

The pontoon causeways also began to arrive off the American beaches throughout 7 June. LSTs either towed two two-by-thirty causeway sections, or one section with a blister or a three-by-seven causeway tug. The causeway team at Omaha received orders to hold off installation until 9 June. When the Seabees commenced installation of Easterly Causeway No. 1, beach examinations revealed

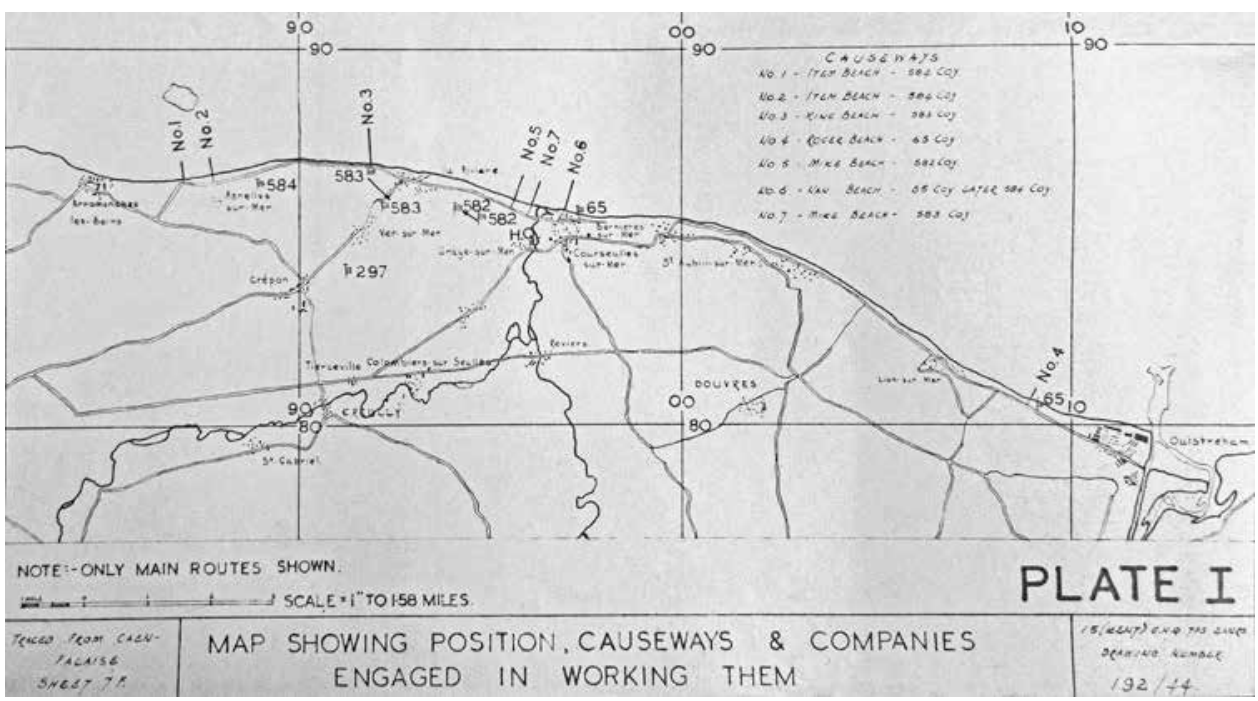

Map showing positions of causeways built and maintained by Royal Engineers from the 15 (Kent) GHQ Troops Engineers. (WO 205/1193, National Archives, Kew, London, United Kingdom)

in-Charge, Gold Beach, to Naval Commander, Force "G," 22 June 1944, DEFE 2/416, NA-Kew.

${ }_{125}$ Symonds, Neptune, 317; memorandum, subject: Action Report - Seabee Activities on Far Shore; 25th NCR, "Report of Activities," 12, 15; Director (B-1), Advance Base Department, BuDocks, memorandum, subject: Report on use of N.L. Pontoon Equipment by Amphibious Forces on Normandy Beach, undated, SMA. 
a shorter length would be sufficient for unloading, resulting in a doubled causeway width of 28 feet. From 11-17 June, Causeway No. 1 unloaded twelve LCTs, fourteen rhino ferries, and ninety-five miscellaneous craft totaling 746 vehicles, 3,500 tons of bulk cargo, and 8,695 personnel. Causeway No. 2 unloaded a further fortynine LCTs and 139 smaller craft, delivering approximately 4,700 personnel ashore between 16-17 June. ${ }^{126}$ At Utah, CBD 1006's causeway detachment managed to install most of Easterly Causeway No. 1 on 8 June and complete it the following day. Pontoon causeway sections for the Westerly Causeway No. 2 arrived on 11 June and the entire causeway was completed in four days. At Utah, from 6-13 June, eighty-five percent of all vehicles and cargo came ashore thanks to Laycock's pontoons, either as ferries or causeways. ${ }^{127}$ In a report to BuDocks, a CEC officer noted how "Army officers were well pleased with the causeway operation, mainly because the troops and vehicles were landed dry." Causeway crews managed to unload from 20,000 to 30,000 troops without interfering with the unloading of vehicles. For the latter, Seabees would occasionally handle the trucks themselves to make up for Army shortages of drivers. ${ }^{128}$

Construction of the massive mulberry harbors loomed in the water behind the causeway construction. Work began on both mulberries on 7 June, with the Seabees of the 25th NCR working furiously to install Mulberry A off Omaha, an effort rewarded when, on 16 June, LST-342 became the first vessel to unload at one of the specialized Lobnitz pierheads. A second pier came online at Mulberry A by 18 June, with 11 LSTs discharging vehicles at a rate of one every 1.6 minutes. ${ }^{129}$ At Arromanches, assembly of Mulberry B by the British engineers and soldiers of No. 1 Port Construction and Repair Group proceeded at a more deliberate pace; the harbor would not achieve its target figure for unloading 6,000 tons of supplies daily until 9 July, and even then the LST piece still remained incomplete. ${ }^{130}$ By 18 June, the US Navy had landed 116,000 tons of supplies, 41,000 vehicles, and 314,514 personnel at Omaha and Utah. Arguably at least a third, perhaps as much as a half of the supplies and vehicles came ashore via Laycock's pontoons. Over the same period, the British and Canadian forces at Gold, Juno, and Sword beaches landed 102,000 tons of supplies, 54,000 vehicles, and 314,547 personnel. ${ }^{131}$

For the British, assembly of the causeways commenced on 7 June and

\footnotetext{
${ }^{126}$ Memorandum, subject: Action Report - Seabee Activities on Far Shore; 25th NCR, "Report of Activities," 12-13, SMA.

${ }^{127}$ Memorandum, subject: Action Report - Seabee Activities on Far Shore; 25th NCR, "Report of Activities," 15, SMA.

128 Director (B-1), Advance Base Department, BuDocks, memorandum, subject: Report on use of N.L. Pontoon Equipment by Amphibious Forces on Normandy Beach, undated, SMA.

129 Stanford, Mulberry, 137-75; Morison, France and Germany, 165-66; Hartcup, Code, 108-22.

130 William Tennant to Allied Naval Commander-in-Chief, Expeditionary Force, 30 August 1944, DEFE 2/422, NA-Kew; Hartcup, Code, 108-22.

131 Gordon A. Harrison, The European Theater of Operations: Cross-Channel Attack (Washington, DC: Office of the Chief of Military History, 1951), 423. Hartcup's figures from June 6-19 list American totals of 124,404 tons of supplies, 43,586 vehicles, and 332,269 personnel, and British totals of 120,729 tons of supplies, 50,400 vehicles, and 286,586 personnel. Hartcup, Code, 122.
} 
additional sections, or sinkers, arrived up to 5 July. During the tows, ten two-bythirty sections, six blisters, and one tug were completely lost in the channel. Seven causeways (later reduced to six) were constructed but shifted around as the British changed their beach procedures. By 11 June, three causeways, two at Juno and one at Gold, opened for operations with a second causeway at Gold opening on 12 June. Causeway No. 4 was the lone causeway on Sword, made up from pieces of Causeway No. 2 which was abandoned due to silting and cross currents. Causeway No. 4 in turn was dismantled when the decision was made to land all personnel and vehicles on only Juno. Unlike the American causeways, the British staggered Causeways No. 1 and No. 6 to avoid bad patches of beach. Only Causeway No. 7 featured a doubled width like at Omaha. ${ }^{132}$

With the causeways producing results and Mulberry A operational, the Allied Expeditionary Forces confronted a new, unanticipated enemy: Mother Nature. On 19 June, a Channel storm turned Omaha and Utah into steel junkyards. A surprisingly fierce summer gale brought winds of thirty knots and waves of eight to ten feet on the exposed beaches and six to eight feet inside the harbor shelter. The rhinos and tugs were beached at the onset of the rising gale and the warping tugs anchored in the harbor area. The storm continued for days until winds began to lessen in the afternoon and evening of 22 June.

The morning light of 23 June revealed the extent of the damage to the artificial harbors. Mulberry A had all its piers damaged, two-thirds of the breakwater destroyed, and the blockship breakwater damaged. Mulberry B fared better, thanks in part to the Calvados Shoals and the tighter assembly of its breakwaters, although the outer breakwater still suffered several destroyed units and the pierheads sustained damage. ${ }^{133}$ The causeways inside Mulberry B were driven ashore by heavy surf and damaged by other craft, but all were repaired, replaced, and operational once the weather and seas calmed. ${ }^{134}$ At Gold and Sword beaches, only two out of 14 rhinos were operational after the storm. Royal Engineers managed to get eight British rhinos operational, but most of these had ruined engines. ${ }^{135}$

At Mulberry A, 286 odd ships and landing craft littered the beach. All twenty rhinos at Omaha suffered damage when other craft and wreckage collided with the ferries, with damage to the outboard pontoons, angles, and the outboard motors. Both causeways experienced considerable scouring and silting of sand along the pontoons, although Westerly Causeway No. 2 suffered no physical damage thanks to its location inside the Mulberry breakwaters. Easterly Causeway No. 1, however, suffered broken angles at the first and second blisters when floating breakwaters

\footnotetext{
13215 (Kent), “Technical and Other Notes," WO 205/1193, NA-Kew.

133 William Tennant to Allied Naval Commander-in-Chief, Expeditionary Force, 30 August 1944, DEFE 2/422, NA-Kew.

13415 (Kent) GHQ Troops Engineers, "Technical and Other Notes," WO 205-1193, July - August 1944, on Naval Lighterage Pontoon Causeways; memorandum, subject: Operation Neptune, DEFE 2/414, NA-Kew.

135 Memorandum, subject: Operation Neptune, DEFE 2/414; Senior Officer Ferry Control, Gold Area to Naval Officer-in-Charge, Gold Area, memorandum, 9 July 1944, DEFE 2/416, NA-Kew.
} 
broke free and collided with the causeway. The storm drove the pontoon drydock positioned in the harbor up on the beach and damaged the pontoons and flooding pipes.

Despite the destruction, the Seabees kept working. By 23 June at Omaha the men managed to get seven rhinos and Westerly Causeway No. 2 back in service to commence unloading of troops and cargo. At Utah, Seabees counted $212 \mathrm{craft}$ piled up on the beach by 22 June. The next day three rhinos resumed unloading MT ships. The two causeways suffered considerable damage from craft broaching and the underwater currents severely canted Easterly Causeway No. 1. After repairing the individual pontoon units, the Seabees refloated, relocated, and doubled the width of both causeways. Engineers removed the blisters and the doubled width reduced the causeways in length to approximately 1,400 feet. The build-up of forces resumed unabated. ${ }^{136}$

After reviewing the severity of damage to Mulberry A, Commodore William A. Sullivan, the Navy's supervisor of salvage, decided against reconstruction of the harbor. Supreme Commander of the Allied Expeditionary Force, General Dwight D. Eisenhower, agreed with Sullivan's assessment. Those salvageable elements of the harbor were removed and towed to Mulberry B at Arromanches while SHAEF agreed to repair and reinforce the Mulberry A breakwaters to shelter LST and causeway operations. ${ }^{137}$ At Omaha, Seabees refloated all the rhinos and repaired all but the severely damaged RHF-7, whose outboard motors were used to recondition those of two other ferries. The men repaired the pontoon drydock but chose to use the craft as a storage and auxiliary repair barge. In classic Seabee "can do" fashion, damaged pontoons with bent corners found second lives as water, gasoline, and oil storage containers. Others found use as dugouts or water sprinklers. Damaged assembly angles found new life as one of the more famous battlefield innovations of the war: Army engineers cut up and welded sections of the angles into hedgerow cutters for tankers to mount to the front of their M-4 Shermans, creating the appropriately named "Rhino Tank."138

136 Symonds, Neptune, 324-27; Morison, France and Germany, 176-79; Stanford, Mulberry, 17996; Hartcup, Code, 123-28; Navy Department, Bases, Vol. 2, 114-17; memorandum, subject: Action Report - Seabee Activities on Far Shore; 25th NCR, "Report of Activities," 13-16; Director (B1), Advance Base Department, BuDocks, memorandum, subject: Report on use of N.L. Pontoon Equipment by Amphibious Forces on Normandy Beach, undated, SMA; Provisional Engineer Special Brigade Group, "Operation Neptune Report," 157-58, File No. 493F, Reel MP63-9_0081, RG498, NARA.

137 Harrison, Cross-Channel Attack, 426; Symonds, Neptune, 327; Hartcup, Code, 128-29; Edward Ellsberg, The Far Shore (Los Angeles: P-47 Press, 2018), 229-31; William Tennant to Allied Naval Commander-in-Chief, Expeditionary Force, 30 August 1944, DEFE 2/422, NA-Kew.

138 Director (B-1), Advance Base Department, BuDocks, memorandum, subject: Report on use of N.L. Pontoon Equipment by Amphibious Forces on Normandy Beach, undated, SMA; Martin Blumenson, The European Theater of Operations: Breakout and Pursuit (Washington, DC: Center of Military History, 1961), 205-7; Michael D. Doubler, Busting the Bocage: American Combined Arms Operations in France, 6 June - 31 July 1944 (Ft Leavenworth, KS: US Army Command and General Staff College, 1988), 33-35; Jon T. Hoffman, ed., A History of Innovation: US Army Adaptation in 


\begin{tabular}{|l|l|r|r|r|}
\hline Date & Craft/Force & Vehicles & Personnel & Cargo (tons) \\
\hline 8-16 June & Omaha Rhinos & 14,749 & & 33,901 \\
\hline 8-16 June & Utah Rhinos & 4,307 & & 31,580 \\
\hline 6 June - 21 October & Omaha \& Utah Rhinos & 91,495 & & 422,195 \\
\hline 11 June - 29 July & All British Causeways & 13,947 & 115,000 & \\
\hline 22 July - 21 August & Omaha, Wly Causeway No. 2 & 5,824 & 84,101 & \\
\hline
\end{tabular}

Table 5. Vehicles, Personnel and Cargo moved over pontoon structures at Overlord beaches.

The storm hampered but did not halt landing operations. From 8-15 July, the twenty rhinos at Omaha landed 4,500 vehicles and 20,000 tons of bulk cargo, while Utah reached a peak between 22-29 July of 3,500 vehicles ashore with its eleven rhinos. Army divisions continued to march ashore over the causeways which CBD 1006 faithfully maintained until 10 July when Army engineers took over all operation and maintenance. The ferries eventually shifted to other locations, with six towed to Cherbourg and twenty-one relocated to Le Havre where ten served as floats in the harbor development program. As the war moved across France from late summer into winter, additional port facilities came online, negating the need for Utah and Omaha. The former decommissioned on 31 October and the latter on 19 November 1944, with the causeways and all equipment moved to US Naval Advance Bases at Le Havre and Cherbourg. ${ }^{139}$

\section{Evaluation and Conclusion}

Operation Neptune made ample use of the T-series Navy landing pontoons for the buildup of forces after the initial assault. In the area of statistics, the pontoon numbers for use in Normandy are remarkable. Seabees used 22,806 pontoons - a dead weight of 35,218 tons and displacement of 91,225 tons - to assemble rhino ferries and tugs, warping tugs, miles of causeway section, repair and fuel barges, wharfs and drydocks. The men of 15 (Kent) GHQ Troops Engineers in Southampton assembled a further 12,800 pontoons into rhino ferries and causeway sections. These figures represent just under five percent of all T-series pontoons manufactured by the United States during World War II; for the British, this represented forty percent of all pontoons manufactured under patent. ${ }^{140}$

The construction figures pair with the surviving figures of men, machinery, and supplies transported via pontoon seen in Table 3. In the summary report of

War and Peace (Washington, DC: Center of Military History, 2009), 97-101.

139 25th NCR, "Report of Activities," 17-18, 26-27, SMA.

140 25th NCR, "Report of Activities," 8, SMA; House Committee on the Judiciary, Hearings for H.R. 4561, For the Relief of the Estate of Captain John N. Laycock, USN (Retired), 91st Cong., 1st sess., 1969, 49-51; Cong. Rec., 91st Cong., 1st sess., 1969, 115, pt. 27: 35895-98; 15 (Kent), "Technical and Other Notes," WO 205/1193, NA-Kew. The causeways, blisters, and tugs required 7,240 pontoons, with 5,560 pontoons used for rhino ferries. 
the 25th NCR, the rhino ferries at the two American beaches managed a peak daily average during the invasion period of 2,382 vehicles and 8,084 tons of bulk cargo. ${ }^{141}$ Specific figures on the British rhino ferries are unknown, but the British causeways combined transported vehicles and personnel which are slightly higher than the reported figures for Westerly Causeway No. 2 at Omaha. ${ }^{142}$ If this one American causeway's statistics broadly equates with the combined British causeway figures, it is assumed the combined American causeway figures are considerably higher.

Daily supply tonnage figures for the Western Task Force allows a statistical evaluation of the value of the pontoon structures. The figures, taken from a US Army logistical study, indicate that the rhinos handled most of the supplies landed at Omaha until 10 June when LSTs began to beach themselves. A significant jump in the daily tonnage at Omaha next occurred on 11 June when Causeway No. 1 began unloading craft, likewise on 15 June with the completion of Causeway No. 2. Curiously, the tonnage figures at Omaha on 23 June, the day after the Channel storm, are the highest of the entire operation to date despite the damage to Mulberry A. For Utah, the figures are less clear with fluctuating figures, although by 15 June with completion of Causeway No. 2 a notable uptick is obvious compared to 14 June. ${ }^{143}$ For comparison with US Army figures from the period of 8-16 June, the rhinos at Omaha delivered sixty-six percent and at Utah eighty-six percent of all bulk cargo. ${ }^{144}$ The figures seem exceptionally high considering the movement of supplies by the smaller Army DUKWs able to carry 5,000 pounds apiece, LCTs, and the role of the causeways. ${ }^{145}$ If the latter predominantly moved vehicles and personnel then perhaps the figures are not too far removed from reality.

Leadership found several faults with the untried pontoon craft at Normandy. Admiral Ramsay's report on Neptune declared the rhino performance disappointing in the open waters of the English Channel but noted with experience and modification the ferries might prove an effective method of ship to shore ferrying. "In the event too much had to be learned about them in too short a time, especially by the British," he reported. Part of the problem he pinned on manning the ferries with British Army IWT personnel, compared to the rhino performance under the Seabees. ${ }^{146}$ Navy Captain W.D. Wright, Deputy Commander of Assault Force O-2,

\footnotetext{
141 25th NCR, "Report of Activities," 17-18, 26-27, SMA.

14215 (Kent), "Technical and Other Notes," WO 205/1193, NA-Kew; Douglas C. Jardine to Captain Frazier, memorandum, subject: US Army - Mars Omaha, Causeway Operations - Report, 3 September 1944, File No. 493A, Operation Neptune - Communications, Signal, Administrative History Collection, Historical Section, ETOUSA, Reel MP63-9_0080, RG498, NARA.

143 Ruppenthal, Logistical, 416.

144 Memorandum, subject: Action Report - Seabee Activities on Far Shore; 25th NCR, "Report of Activities," 12, 15, SMA.

145 Ruppenthal, Logistical, 332-34, 393-94. DUKW refers to "Designed in 1942; Utility; K (Allwheel drive); W (dual-tandem rear axles)."

146 Bertram Ramsay to Dwight D. Eisenhower, Report by the Allied Naval Commander-in-Chief Expeditionary Force on Operation "Neptune," Appendix 6 - Beach Maintenance, 72, Allied Naval
} 
wrote to Admiral King about Operation Neptune. Wright considered the rhinos "too delicate to operate in moderate surf" and "too unwieldy to be maneuvered among beach obstructions" but praised them for ease in repair and having "proved to be by far the most successful ferry craft in unloading vehicles from MT ships." The sunken causeways he rated a "partial success" for being dangerous in high tides for unloading LCTs which could be easily pushed over the causeways and damaged. ${ }^{147}$ In reply to Wright's assessment, Rear Admiral John L. Hall, Force O's commander, deemed the rhino ferry "an exceedingly valuable craft for the ship to shore transport of vehicles and other wheeled equipment" but he did not address Wright's comment on the causeways. ${ }^{148}$

In after action reports, Rear Admiral Sir Philip Louis Vian, Naval Commander,

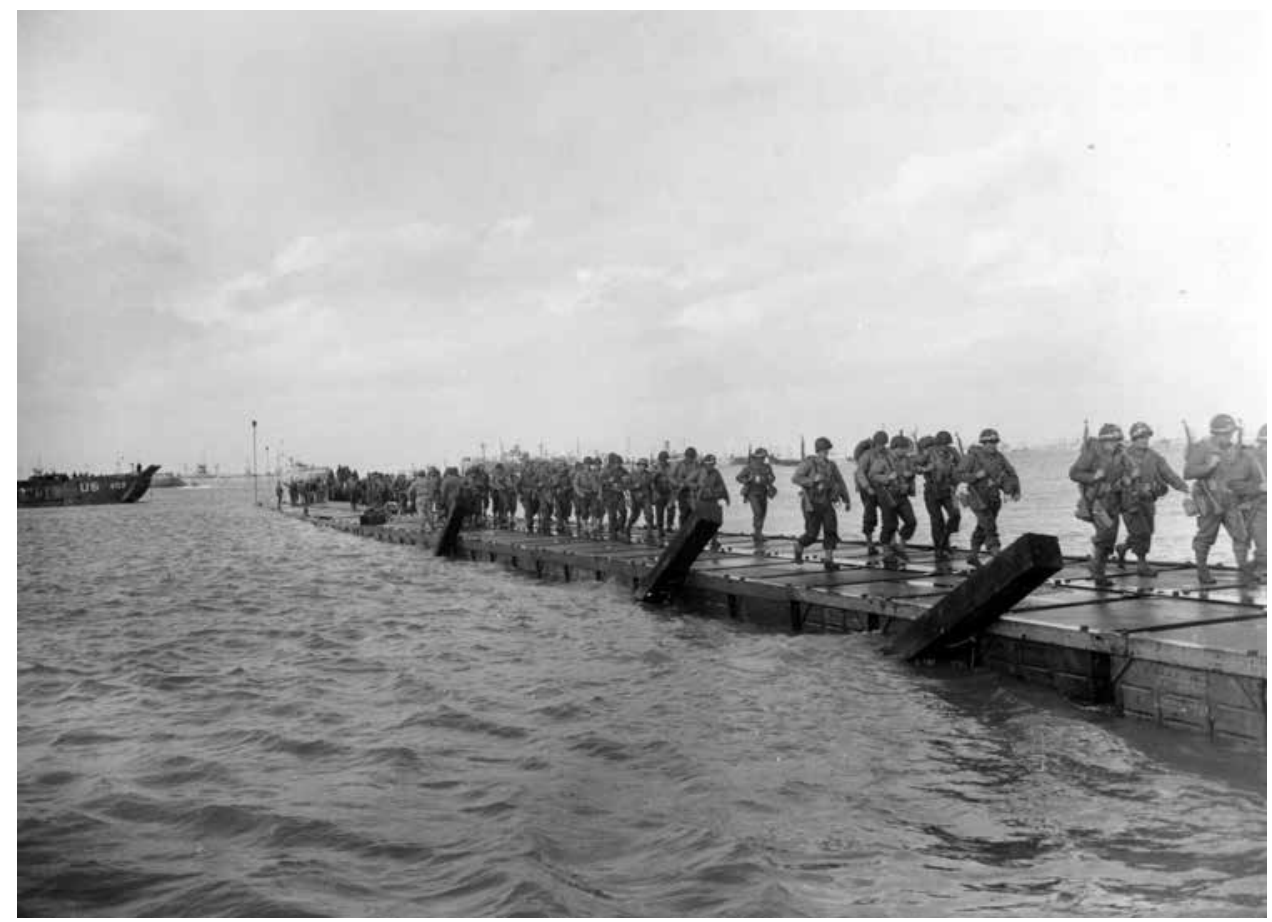

Soldiers marching ashore across pontoon causeways, most likely at Utah Beach. (US Navy Seabee Museum, Port Hueneme, CA)

Commander-in-Chief, Expeditionary Force, Report of Naval Operations in the Invasion of Normandy, France, Reel A1795, WWII-WD, RG38, NARA.

147 W.D. Wright, Deputy Commander, Assault Force O-2, to Ernest J. King, Commander-in-Chief, United States Fleet, memorandum, subject: Action Report - Operation [excised], 4 July 1944, Action Report of Ops, 6/4-17/44 Invasion of Normandy, France, File A9-8, Reel A1027, WWII-WD, RG38, NARA.

148 John L. Hall, Commander, Eleventh Amphibious Force to Ernest J. King, Commander-inChief, United States Fleet, memorandum, subject: First Endorsement - Action Report - Operation Normandy, 25 September 1944, Action Report of Ops, 6/4-17/44 Invasion of Normandy, France, File A9-8, Reel A1027, WWII-WD, RG38, NARA. 
Eastern Task Force, concluded that "the Rhino ferries failed to carry out their planned function." ${ }^{149}$ In particular, the rhinos turned out to be slow and unreliable when unloading LSTs in rough English Channel waters, and "were practically useless on a newly captured beach in rough weather before beach obstacles had been cleared." But on clear beaches in fair to moderate weather, the rhinos were useful in unloading MT ships. ${ }^{150}$ The naval commanders for the Gold and Juno assault forces spoke highly of the pontoon causeways, concluding they "are the only method of landing troops, working parties, etc., dryshod on a flat beach."151 Colonel Eugene M. Caffey, commanding the US Army's First Engineer Special Brigade, reported that the American pontoon causeways "essentially doubled the vehicle landing capabilities of LCTs and Rhinos and thus contributed materially to the success of the operation."152

Comparing the British and American discharge statistics on the causeways, it is evident the British underutilized the causeways. Lieutenant Colonel LRE Fayle, Royal Engineers, commanding 15 (Kent) GHQ Troops Engineers, concluded "[ $\mathrm{t}$ ] he main reason why the causeways were not used more was that the two conditions for which they were designed - namely beaches with impassable clay patches, and unwaterproofed vehicles - were for the most part absent. Had these conditions been present we should have had insufficient causeways to deal with the traffic we should have had." He also acknowledged a lack of awareness about and familiarization of the causeways to the Royal Navy and the Beach Groups early in the operations. Interservice rivalry evidently also played a factor, with Royal Navy personnel ignoring the Royal Engineers on the under-utilized causeways. American LCTs, apparently aware of the causeway utility, eagerly used British causeways, with Fayle commenting that "it is probable that $2 / 3$ rds of the landing craft who used the causeways were American." 153

Commander EW Middleton, Naval Liaison Officer for Pontoon Causeways for the Eastern Task Force, shared similar views with those of Fayle about the limited use of the British causeways. He thought Fayle erred in deciding to build all six causeways at once. One or two longer causeways, accessible 24 hours, would have accelerated unloading compared to six short causeways only accessible at high tide. Middleton concurred with Fayle on the lack of training as the limiting factor on wider causeway usage and reported from his arrival at the far shore on July 3 , he made every effort to make authorities "causeway-minded" which resulted in an uptick in usage. "Up to D+40 [16 July], the four causeways worked had landed 10,000 vehicles and 100,000 men," wrote Middleton, and "[h] ad it been considered advisable or necessary, twice this amount could have been handled

\footnotetext{
149 Memorandum, subject: Operation Neptune, DEFE 2/414, NA-Kew.

150 Memorandum, subject: Report on Operation "Neptune," DEFE 2/418, NA-Kew.

151 Appendix I to Naval Commander Force "G's" No. 0301/6613, 15 July 1944, DEFE 2/417, NAKew.

152 Headquarters 1st Engineer Special Brigade, Eugene M. Caffey, Report on Operation "Neptune" (Utah Beach 6 June 1944 - 24 Oct 1944), DEFE 2/424, NA-Kew.

15315 (Kent) GHQ Troops Engineers, N.L. Pontoon Causeways - Comments and Suggestions, WO 205/1193, NA-Kew.
} 
with ease." $" 154$

Problems aside, the pontoon structures provided American forces with a reliable logistical capability throughout the establishment of the invasion beaches. The rhino ferries - and especially the causeways - provided considerable return on investment for the offloading of supplies within the shelter of the mulberry breakwaters. While the floating piers of the mulberries proved vulnerable to the Channel storm, the simplicity and flexibility of the sunken pontoon causeway meant they could be more quickly restored to operation on site. Although the pontoons exhibited a few faults, most notably the rhino ferry engines, none inhibited their foundational purpose of moving personnel, supplies, and vehicles ashore twentyfour hours a day to build up the lodgement on the continent.

Laycock developed the modular pontoon technology, but Hussey envisioned its wider potential for amphibious operations. The development of the pontoon causeway might never have occurred as an amphibious asset for the US Navy had necessity not inspired the causeway in Hussey's mind. Without Hussey learning of the pontoon technology in early December 1941, the landings in Sicily in July 1943 may well have taken an entirely different form. But Hussey's ideas were for naught without Laycock's ability to develop pontoon structures capable of meeting or exceeding operational needs.

Their Anglo-American working relationship made the naval landing pontoon an unsung hero in the Overlord buildup, and thereafter an essential element of practically every Allied amphibious operation in World War II. The pontoons went into production in the US, UK, and Australia with use on practically every continent on Earth, in war and peacetime. Although the rhino ferries never saw use after Normandy, pontoon causeways found a place in Operation Dragoon and in the numerous amphibious operations in the Pacific Theater in late 1944 and 1945. Navy landing pontoons are not memorable, and not one of the 500,000 Americanmade T6 or T7 pontoons can be found in a military museum in the United States or the United Kingdom. A legacy of the Laycock-Hussey effort lives on in the contemporary Improved Navy Lighterage System (INLS), able to transfer cargo faster and more efficiently in support of the US Navy's seabasing operations in the twenty-first century. The usage of INLS to bridge the ship to shore gap in amphibious operations, however, remains unknown and may necessitate a return to the light, flexible T-series landing pontoon. ${ }^{155}$

\section{Dr. Frank A. Blazich, Jr. is a Curator of Modern Military History for the Division of Political and Military History at the Smithsonian Institution's National Museum of American History, Washington, DC. (Contact:blazichf@si.edu)}

\footnotetext{
154 E.W. Middleton to A.N.C.X.F, memorandum, subject: N.L.O. Pontoon Causeways - Final Report, 31 July 1944, DEFE 2/1132, NA-Kew.

155 "NAVFAC Reinvents Versatile Lighterage System," Navy Civil Engineer 40, no. 3 (2003): 1213; "Whatever Floats Your Tank: the USN's Improved Navy Lighterage System," Defense Industry Daily, 9 September 2013, https://www.defenseindustrydaily.com/whatever-floats-your-tank-theusns-improved-navy-lighterage-system-02251/ (accessed 3 May 2021).
} 